\title{
Modeling Green Roof Potential to Mitigate Urban Flooding in a Chinese City
}

\author{
Li Liu ${ }^{1}$, Liwei Sun ${ }^{2}$, Jie Niu ${ }^{3, *}$ and William J. Riley ${ }^{4}$ \\ 1 College of Construction, Jiangxi Normal University, Nanchang 330022, China; liuli@mail.nankai.edu.cn \\ 2 Southern Marine Science and Engineering Guangdong Laboratory (Guangzhou), \\ Institute of Environmental and Ecological Engineering, Guangdong University of Technology, \\ Guangzhou 510006, China; LiweiSun1990@hotmail.com \\ 3 Institute of Groundwater and Earth Science, Jinan University, Guangzhou 510632, China \\ 4 Earth Science Division, Lawrence Berkeley National Lab, Berkeley, CA 94720, USA; wjriley@lbl.gov \\ * Correspondence: jniu@jnu.edu.cn
}

Received: 3 July 2020; Accepted: 17 July 2020; Published: 22 July 2020

\begin{abstract}
The Middle and Lower Reaches of the Yangtze River (MLRYR) region, which has humid subtropical climate conditions and unique plum rain season, is characterized by a simultaneous high-frequency urban flooding and reduction in groundwater levels. Retrofitting the existing buildings into green roofs is a promising approach to combat urban flooding, especially for a densely developed city. Here, the application potential of the Green Roof System (GRS) and the Improved Green Roof System (IGRS) designed to divert overflowing water from green roofs to recharge groundwater were analyzed in a densely developed city, Nanchang, China. For the first time, the influence of GRS on the hydraulic condition of Combined Sewage System/Storm Water System (CSS/SWS) is analyzed, which is a direct reflection of the effect of GRS on alleviating urban flooding. The simulation results show that GRS can retain about $41-75 \%$ of precipitation in a 2-hour timescale and the flooding volumes in the GRS/IGRS region are $82 \%$ and $28 \%$ less than those of the Traditional Roof System (TRS) in 10- and 100-yr precipitation events, respectively. In the continuous simulations, GRS also enhances Evapotranspiration (ET), which accounts for $39 \%$ of annual precipitation, so that reduces the cumulative surface runoff. Considering the IGRS can provide more hydrological benefits than the GRS under the same climate conditions, we may conclude that the widespread implementation of both the GRS and the IGRS in Nanchang and other densely developed cities in the MLRYR region could significantly reduce surface and peak runoff rates.
\end{abstract}

Keywords: Green roof; urban flooding; groundwater recharge; hydrological benefit; rainwater retention

\section{Introduction}

The permeability of urban land has been changed substantially with urban sprawl [1-3] since the original permeable soil is replaced by relatively impervious surfaces. As a result, the Middle and Lower Reaches of the Yangtze River region (MLRYR), one of the most densely populated areas in China, is suffering from serious urban flooding and groundwater depletion. On the one side, total annual precipitation in this region has increased significantly since the end of the 1970s. In addition, there is a decrease in the number of precipitation days and a significant increasing precipitation intensity as proved by previous studies [4-9]. On the other side, drought in the MLRYR has significant sustainability in the past 50 years with increasing intensity over the past two decades [10]. For example, severe droughts have been detected in the MLRYR in 2000, 2001, 2004, 2007, 2011, and 2013 [11]. Therefore, the MLRYR climatic characteristics result in relatively high frequency of urban flooding and groundwater depletion. 
Green Roof Systems (GRS), which include a substrate for vegetation, have considerable potential to alleviate urban flooding [12-15]. In comparison to a Traditional Roof System (TRS), the GRS can intercept, detain, and delay surface runoff $[1,16]$. For example, the evaluated results in Li and Babcock (2014) showed that the GRS could reduce total runoff volume by $30-86 \%$, peak flow rates by $22-93 \%$, and delay peak surface runoff flows by up to $30 \mathrm{~min}$ [16]. Furthermore, GRS is feasible to apply since it can be retrofitted to existing buildings and does not require as much additional space as other approaches. Considering that existing buildings in many cities account for a large fraction (often $40-50 \%$ ) of impermeable area [15,17], GRS is a potential Low Impact Development (LID) method to address urban flooding issue in this region because it can be implemented widely.

Recognizing the advantages of GRS, more and more research has been devoted to this field such as measuring the rainwater retention of green roofs over a certain period of time [18-20], comparing the rainwater retention amount of green roofs under different rainfall intensities [21,22], detecting the impact of roof slope and thickness of the substrate on the retention effect [23-28], comparing the rainwater retention ability of common roofs, green roofs and white roofs $[29,30]$, and the selection of green roof vegetation [31-33]. Previous research has shown that GRS performance depends strongly on climate condition $[2,15,34]$, rooftop configuration [16,29,35], and plant species [36,37].

However, the existent literature is scarce in the following aspects:

1. Few studies focus on the application potential of GRS in the MLRYR region with its unique climate condition that is the main factor determining the performance of GRS. In the MLRYR region, the studies on GRS mainly focus on landscape design, vegetation selection, and energy saving [38-40], and only a few studies on the stormwater retention capacity [41-43]. These studies, however, did not aim at the special climate characteristics of MLRYR, nor did they run the simulation for a long period with the long-term rainfall data. They only used the experimental method to analyze the short-term rainfalls. Therefore, it is necessary to study long-term rainfall for many years and short-term rainfall with different intensities according to the rainfall characteristics of MLRYR, especially the unique plum rain season every year.

2. Previous research did not give a comprehensive analysis of the important effect of evapotranspiration in the hydrodynamic process of GRS [44-47]. We therefore need to better understand the evapotranspiration of GRS by analyzing the Potential Evapotranspiration (PET), Actual Evapotranspiration (AET), and Reference Evapotranspiration (RET).

3. Although there are many researches on the retention and detention of GRS, these studies did not analyze the mitigation potential of GRS for urban flooding by calculating the overload of Combined Sewage System/Storm Water System (CSS/SWS), which is the most direct part to determine whether urban flooding will occur.

4. Many studies have recognized the effect of soil layer on the retention efficiency of GRS, but the sensitivity of soil parameters was not comprehensively analyzed which is important because each soil parameter has a different effect on the retention results. The sensitivity analysis of soil parameters will be helpful to the structural design of GRS in future studies, so as to obtain better retention efficiency.

Moreover, considering that most surface runoff is discharged via the drainage layer of GRS into the CSS/SWS in heavy precipitation because the retention volume of GRS decreases as precipitation intensity increases [16], we propose an Improved Green Roof System (IGRS) that combines green roof and rooftop disconnection to decrease drainage system loads and better recharge groundwater. Therefore, the objectives of this work are to address the following questions:

1. What are the impacts of the GRS and IGRS on hydrology characters (e.g., surface runoff, flood, evaporation, and infiltration) of an urban catchment in Nanchang that has typical rainfall characteristics of MLRYR?

2. Based on the comprehensive analysis of PET, AET, and RET, what role does evapotranspiration play in the hydrological cycle of GRS?

3. Does the GRS or IGRS have the potential to be applied in cities like Nanchang? 
To answer these questions, this study simulated the hydrological process of runoff, flooding flow, evaporation, and infiltration of GRS under different rainfall intensities and durations, and tested the sensitivity of soil parameters of GRS, so as to explore the potential of GRS to mitigate the urban flooding problems. The novelty of the urban flooding mitigation study stems from the fact that the hydraulic condition of CSS/SWS is the most direct factor to decide whether urban flooding will occur. We analyzed flooding nodes and overloaded conduits of CSS/SWS as well as runoff retention of GRS and IGRS under the unique climatic and high-density developed conditions in MLRYR. On the whole, we first analyzed the potential application of GRS to reduce surface runoff and peak flow rates and recharge groundwater in a densely developed city in the MLRYR region. We performed the analyses using the United States Environmental Protection Agency (USEPA) Storm Water Management Model (SWMM). Then we explored the potential and impacts of green roof application by analyzing hydrological characteristics of TRS, GRS, and IGRS in terms of surface runoff, flood, evaporation, and infiltration, to see if the GRS or IGRS is superior to the TRS in the studying city. Finally, we synthesized and discussed results in Section 3.

\section{Methods}

\subsection{Study Site}

Nanchang $\left(28^{\circ} 68^{\prime} \mathrm{N}, 115^{\circ} 89^{\prime} \mathrm{E}\right)$, the capital of Jiangxi province, China, and a highly populated and urbanized area (5.46 million inhabitants in $335 \mathrm{~km}^{2}$ ) in the MLRYR, was selected as the study region for spatial analysis and hydrologic modeling (Figure 1). The open water bodies of each district of Nanchang city are natural flood storage areas that have formed over thousands of years. However, a large number of natural rivers and lakes have been narrowed, blocked, and landfilled during the rapid urbanization process. Furthermore, the permeable soils have been replaced by hard ground and impervious roofs, which would hinder groundwater recharge and increase the loading of drainage systems. As a result of the unique climate characteristics of the MLRYR region and the human factors in urban expansion, Nanchang is also suffering from urban flooding and groundwater depletion.

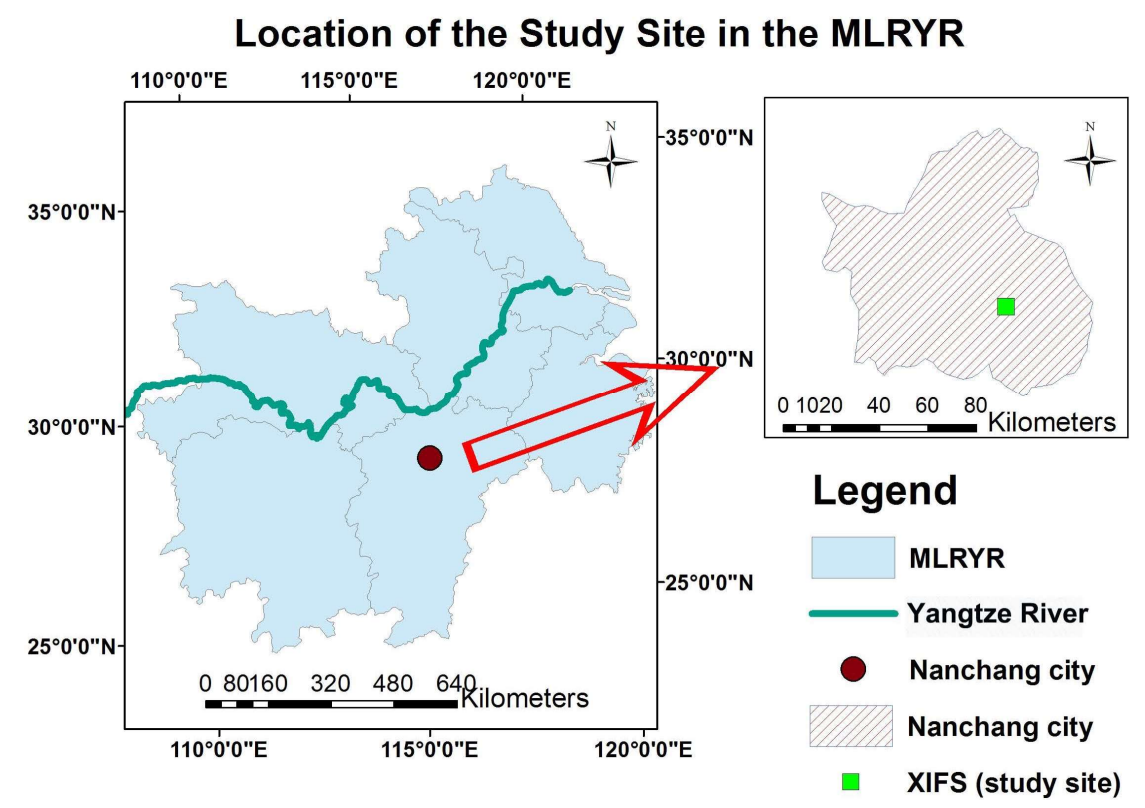

Figure 1. Location of the study site in the Middle and Lower Reaches of Yangtze River Region.

The city has humid subtropical (Cfa) [48] climate conditions. The mean yearly temperature is about $17.5^{\circ} \mathrm{C}$, with July being the hottest month. The mean annual precipitation is about $1600 \mathrm{~mm} \mathrm{yr}^{-1}$, most of which falls during the plum rain season (June-July) and the typhoon season (July-September). 
The plum rain season, with characteristics of persistent precipitation, is a specific and important climate phenomenon over the MLRYR region, South Korean Peninsula, and south-central Japan from June to July, associated with the East Asian Monsoon (EAM) [49,50]. The EAM system includes the cold dry northwestern East Asian Winter Monsoon (EAWM) and the warm and moist southeastern East Asian Summer Monsoon (EASM) [51]. The beginning of plum rain is the main part of the EASM system that occurs over eastern China, the South China Sea, Korea, Japan, and the adjacent seas [52-59]. In Nanchang, during the plum rain season, the northward warm moist EASM and the shallow cold air mass of Central East China from the north meet and create a quasi-stationary front, creating high precipitation in June and July (243.8 and $306.7 \mathrm{~mm} \mathrm{month}^{-1}$ in June and July, respectively) [60,61]. From July to September, abundant precipitation is associated with typhoons. As a result of rapid urbanization, the storm water network in this city is very sensitive to intense precipitation, which can cause local flooding.

Groundwater dynamics in Nanchang city are affected by extraction, rivers, and rainfall [62]. As a result of the overexploitation of groundwater, three big regional cones of depression were formed during the 1960s [63]. There continues to be an expansion of the cones of depression, and groundwater levels have dropped, which has also influenced by a multi-decadal drought $[62,63]$.

Evaporation, humidity, radiation, and wind speed data in 2015 as well as the precipitation and temperature data in 1985-2015 for Nanchang city were provided by the China Meteorological Administration. All data were daily recorded. The missing precipitation data in the total data per year is shown in the Figure S1. All days without precipitation data are considered zero rainfall because the proportion of missing data is within $6 \%$, and most of them are not in rainy season. Continuous precipitation data from 1985 to 2015 were used in three aspects: first, to analyze seasonal variations of rainfall; second, to synthesize 2-year, 10-year, and 100-year precipitation events; and third, to analyze cumulative changes of surface runoff and evaporation with the temperature data. Daily evaporation, humidity, wind speed, and precipitation data in 2015 were used to calculate ET by different methods. The 31-year precipitation dataset has a strong seasonal cycle, with distinct wet (from February to August) and dry (from September to January) seasons (Figure 2). The wet season precipitation accounts for $79.1 \%$ of annual total precipitation. Monthly data showed that the maximum rainfall always occurs in June, with a mean precipitation of $320 \mathrm{~mm} \mathrm{month}^{-1}$.

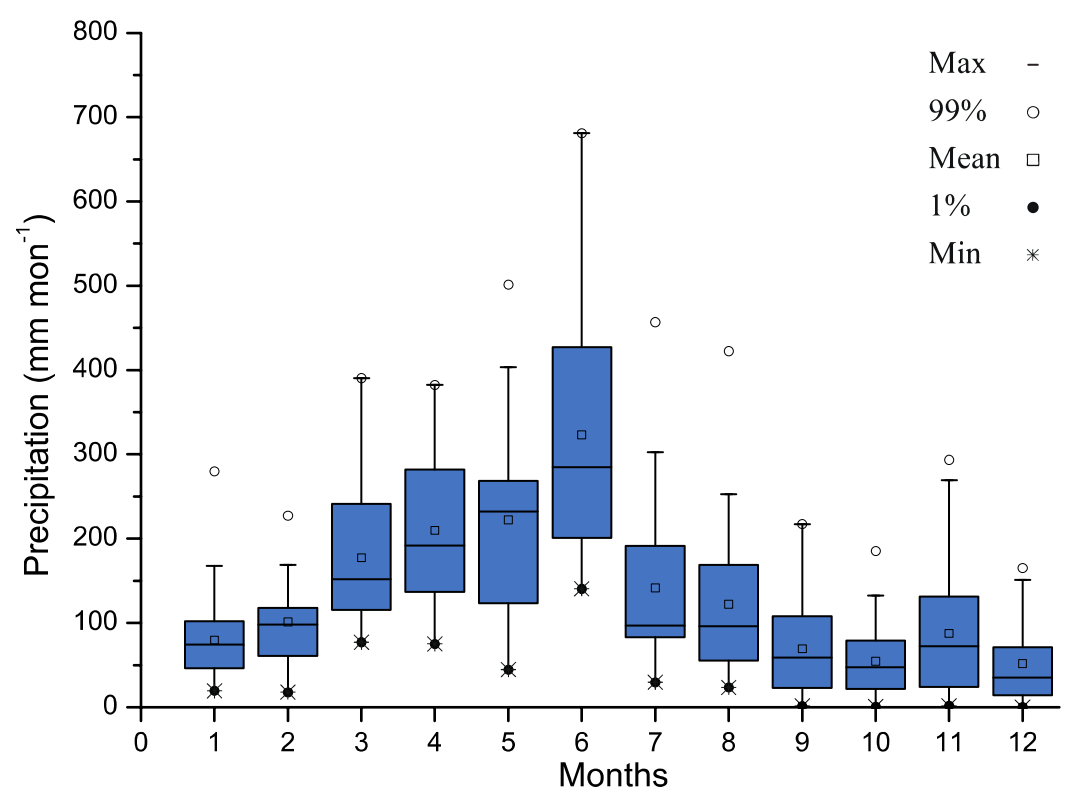

Figure 2. Seasonal variation of precipitation in Nanchang.

The study was conducted on Xiangjiang International Furniture Square (XIFS) (28 $39^{\prime} 16.23^{\prime \prime}$ N, $115^{\circ} 56^{\prime} 36.26^{\prime \prime}$ E) (Figure 3a). XIFS is a commercial service facility area located in the northern part 
of Nanchang city. The total area of XIFS is $0.16 \mathrm{~km}^{2}$ with a building density of $45 \%$ sharing the homogeneous climate condition as well as the soil and vegetation conditions. The buildings are all flat roofs with an average slope of $2 \%$.
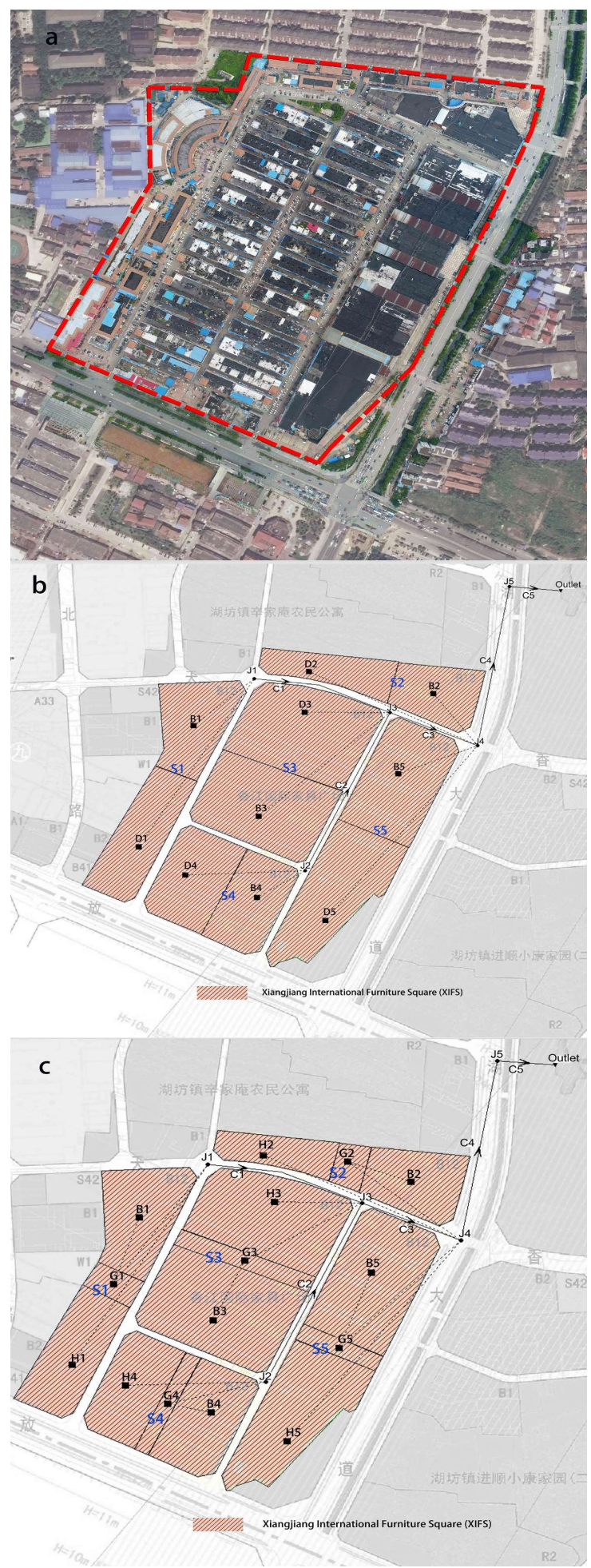

Figure 3. Map of the study site. (a) The aerial photograph of the Studying District (Xiangjiang International Furniture Square (XIFS)); (b) division diagram of XIFS catchment for the comparison between the Traditional Roof System (TRS) and the Green Roof System (GRS); (c) division diagram of XIFS catchment for the comparison between the GRS and Improved Green Roof System (IGRS). 


\subsection{Methodology}

The GRS typically contains four layers (from top to bottom): vegetation, soil, filter, and drainage [25]. The single precipitation events and continuous precipitation for three types of roof systems (i.e., TRS, GRS, and IGRS) were simulated using the Storm Water Management Model (SWMM, V. 5.1) which contains the LID package that accommodates green roofs and other new techniques [12]. Parameters used to describe the features of the four layers of a green roof can be specifically inputted in SWMM [12]. Depending on the thickness of the growing media and the vegetation, green roofs are classified as intensive and extensive types [64]. The intensive type typically has thick growing media and diverse vegetation including grass, shrubs, and trees, whereas the extensive type has thinner $(\leq 15 \mathrm{~cm})$ media and drought enduring vegetation $[1,65]$. Extensive green roofs were chosen in this case to build retrofit since it has lower weight loads; is easier to build; and can be used in new or existing buildings [66].

\subsubsection{Comparison between TRS and GRS}

\section{Modeling of TRS and GRS}

Two scenarios are studied in the comparison between TRS and GRS: a traditional impervious design, and a typical GRS design. The SWMM was performed in seven steps: (1) Divide the study catchment XIFS into five sub-catchments $S_{i}(i=1,2 \ldots 5$; Figure $3 b)$ according to the existing roads, because surface runoff is discharged into the drainage pipeline under the road. Each sub-catchment $S_{i}$ was divided into $B_{i}(i=1,2 \ldots 5)$ representing characteristic buildings and $D_{i}(i=1,2 \ldots 5)$ representing impermeable ground (Figure $3 b$ ). $B_{i}$ are given impermeable parameters in the TRS scenario and green roof related parameters in the GRS scenario. The area of green land is negligible in this study since it only accounts for a small part of the study area $(\sim 1 \%)$ with the remainder being impermeable houses and hardened ground. For model assumption, the average surface slope is $0.2 \%$, depth of depression storage on the impervious area is $1.27 \mathrm{~mm}$, and percent of the impervious area with no depression storage is $25 \%$. From the regulatory detailed planning documents of the XIFS, the building density of the study area is $45 \%$, so $B_{i}=0.45 S_{i}, D_{i}=0.55 S_{i}$, and $B_{i}+D_{i}=S_{i}(i=1,2 \ldots$ 5). (2) Define all the $B_{i}$ parts as impervious sub-catchments with properties representative of TRS. (3) For single event simulations, use three synthetic designs that represent the 2-, 10-, and 100-year precipitation events to calculate runoff volume. The precipitation duration was set as $2 \mathrm{~h}$ to facilitate comparison between three different precipitation intensities. These idealized precipitation events were synthetized from the 31-year historical data in Nanchang city. (4) For continuous simulations, we used long term continuous precipitation data to calculate the hydrological responses of TRS and GRS. The daily precipitation was used as model input. (5) Use the SWMM to set up a green roof treatment simulation for all the $\mathrm{B}_{i}$ parts, and describe physical properties of the simulated GRS. We used the green roof type as LID type in SWMM. The relevant model parameters, such as substrate thickness, field capacity, wilting point, saturated hydraulic conductivity, and void fraction were determined from sensitivity analyses. The initial moisture content is clearly critical because there will clearly be a far higher level of retention (runoff reduction) if the roof is assumed to be dry, compared with a roof that is already wetted to field capacity (zero retention). For simplicity, we only consider initial condition of dry soil moisture content. (6) Repeat step (3), i.e., the single event simulation for GRS. (7) Repeat step (4), i.e., the continuous simulation for GRS. Single event simulation results for TRS and GRS can be obtained from steps (3) and (6) and continuous simulations results for TRS and GRS can be obtained from steps (4) and (7), respectively. As a result that Bioretention cell type is also a commonly used LID type in literature to simulate the behavior of green roof $[67,68]$, steps (5), (6), and (7) were repeated by using the Bioretention cell type in SWMM.

Considering the current climate condition of Nanchang, the capacity of most of CSS/SWS are insufficient and cannot meet the latest design standards of China. The conduits $C_{i}(i=1,2 \ldots 5)$ (Figure $3 b$ ) set up in the study area are all redesigned in accordance with the latest Outdoor Wastewater Engineering Code issued by the Ministry of Housing and Construction of the People's Republic of 
China in 2016. In this way, we can objectively study how green roofs alleviate urban flooding problem as an innovative rainwater storage and drainage method. According to the Code, the surface runoff volume is calculated by storm intensity calculation formula derived from Chicago hyetograph method and combined with surface runoff coefficient. For Nanchang city, the rainfall intensity is:

$$
q=\frac{1598\left(1+0.69 \log _{10} P\right)}{(t+1.4)^{0.64}}
$$

where

$$
\begin{aligned}
& q: \text { rainfall intensity }\left(10^{-3} \mathrm{~m}^{3} \mathrm{~s}^{-1} \mathrm{ha}^{-1}\right) \\
& t: \text { rainfall duration (min) } \\
& P \text { : recurrence period (year) }
\end{aligned}
$$

The diameter of the conduit is calculated on the basis of Chézy formula:

$$
\begin{gathered}
v=\frac{1}{n} \times R^{\frac{2}{3}} \times i^{\frac{1}{2}} \\
D=\sqrt{\frac{4 \times 10^{-3} \times \varphi \times q \times A}{\pi \times v}}
\end{gathered}
$$

where

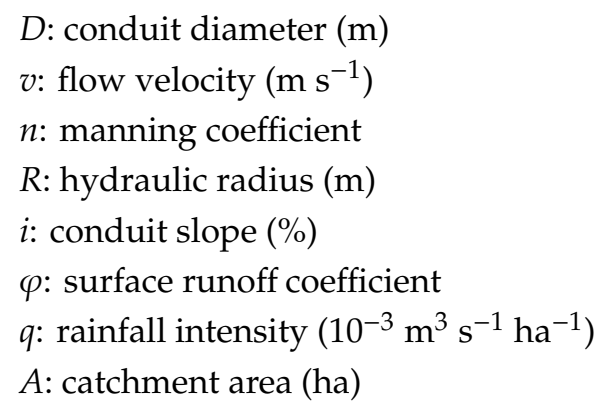

For single event simulations, the 2-, 10-, and 100-year precipitation events are synthesized based on 31 years of rainfall data in Nanchang. Firstly, the Gamma distribution was assumed and fit to the precipitation data because it (Pearson's $\gamma$ ) has been widely accepted to fit the probability distribution of short-duration precipitation in central and southeastern China [69-73]. Since the data obtained are the daily precipitation, there is no distinction of the specific hours of rain per day. Secondly, the precipitation with recurrence periods of 2-, 10-, and 100-years were selected according to probability $p=1 /(365 \times 2)$, $p=1 /(365 \times 10)$, and $p=1 /(365 \times 100)$ after fitting gamma distribution with 31-year daily precipitation data. Thirdly, the Chicago Design Storm (Rainfall Type II) curve was used to calculate the hourly precipitation for the three different recurrence periods. Finally, the maximum $2 \mathrm{~h}$ of 2-, 10-, and 100-year precipitation were chosen for the simulations because the maximum rainfall occurs at $2 \mathrm{~h}$ of noon in each recurrence period and the design time of rain pattern in many literatures is $2 \mathrm{~h}$ also (Figure 4) [74-79]. For continuous simulations, SWMM was firstly used to calculate and analyze the cumulative changes of surface runoff and evaporation by performing GRS simulations on the basis of 31-years precipitation and temperature data. Then the differences of yearly surface runoff and evaporation between GRS and TRS were compared with daily precipitation, evaporation, humidity, temperature, and wind speed data of 2015 being applied. 


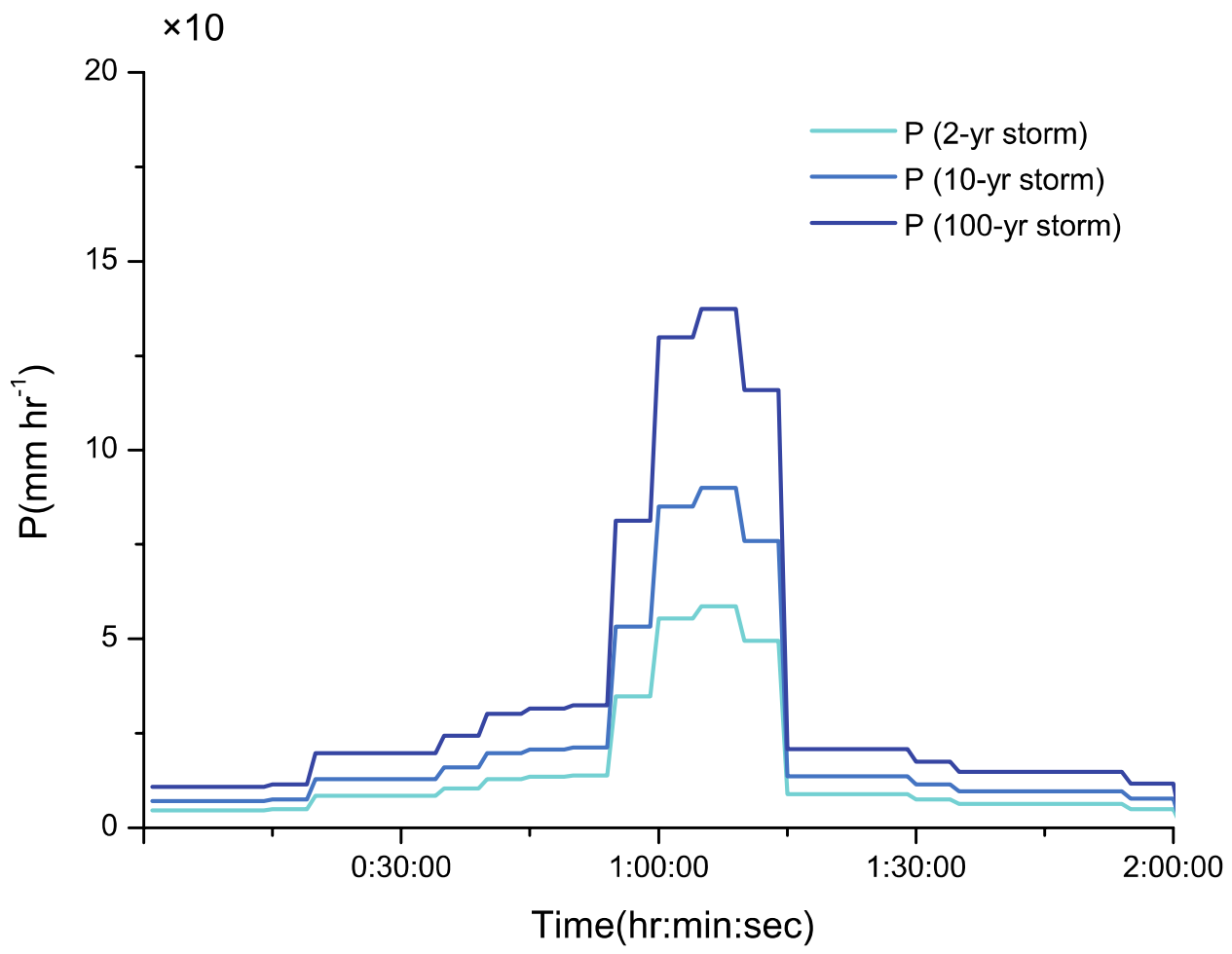

Figure 4. Two hours Precipitation of 2-yr, 10-yr and 100-yr Storms.

For the flow routing model, the kinematic wave equation was selected because it is numerically stable, computationally efficient, and appropriate for heavy precipitation simulations [80]. Manning's roughness coefficients $(n)$ were set as 0.011 for impervious areas and 0.04 for vegetated areas [80].

\section{Sensitivity Analysis of Soil Parameters}

The relevant soil parameters in the GRS model were chosen from our sensitivity analysis. Total 14 parameters are required to input in the SWMM: berm height, vegetation volume fraction, surface roughness, conductivity slope, surface slope, drainage mat thickness, drainage void fraction, drainage roughness parameters, soil thickness, soil porosity, field capacity, wilting point, conductivity, and suction head. Among these parameters, the first 8 are defined in the manual of SWMM 5.1 with definite range of values, and changes in these parameters in the range of maximum and minimum values have little effect on the surface runoff in our tests by simply adjusting the values of the parameters (Table 1). However, soil thickness does have an effect on water storage capacity. The soil thickness is usually $50-150 \mathrm{~mm}$, and the interception rate of rainwater would reduce with the decrease of the thickness of the soil layer $[1,81]$. In order to achieve good storage effect, the maximum thickness of extensive green roof, $150 \mathrm{~mm}$, was used in this simulation. The parameters like substrate composition, structure, and texture (hence pore distribution) are not optional in the SWMM. Therefore, only five important parameters were chosen for sensitivity analysis: saturated hydraulic conductivity, suction head, porosity, field capacity, and wilting point. Firstly, we analyzed the five parameters in the whole point view of the 11 groups of soil texture types (sand, loamy sand, sandy loam, loam, silt loam, sandy clay loam, clay loam, silty clay loam, sandy clay, silty clay, and clay) provided in the SWMM manual. In the cases of an extensive green roof, although lightweight and coarse-grained engineered mixtures are usually used comprising crushed brick or pumice mineral fraction and small amounts of fines and organic matter, we still measured all the 11 groups of soil texture types in the SWMM manual to achieve the integrity of the sensitivity analysis. Moreover, uncertainty analysis is necessary because a variety of materials may be used and even fixed materials also have great uncertainty in parameter measurement. Therefore, 11 groups of soil texture types are considered in the first step and the Monte 
Carlo method was used to select the four groups (maximum, minimum, median, and average) of reference values for testing [80] (Table 2). Secondly, as the practical application of soil in green roofs, three sets of reference values were selected, one of which is the value used by other scholars in a reference literature [12]; the other two groups are the maximum and minimum values of six sets of data from silt clay to silt loam in the SWMM manual because the soil characteristics of green roof is generally between silt clay and silt loam [80] (Table 2). The corresponding objectives of the sensitivity test are: evaporation, runoff, initial LID storage, and final storage. We chose the vegetation volume fraction (i.e., volume occupied by leaves and stems) to be in the range of $0-0.2$ and the ratio of void volume to total volume in drainage layer to be $0.5-0.6$ [80].

Table 1. The test results of insensitive parameters in the GRS model.

\begin{tabular}{|c|c|c|c|}
\hline Parameters & $\begin{array}{l}\text { Surface Runoff } \\
(\mathrm{mm})\end{array}$ & $\begin{array}{l}\text { LID Drainage } \\
(\mathrm{mm})\end{array}$ & $\begin{array}{c}\text { Final Storage } \\
(\mathrm{mm})\end{array}$ \\
\hline \multicolumn{4}{|l|}{ Berm Height (mm) } \\
\hline 0 (ref) & 1029.123 & 909.530 & 22.613 \\
\hline 5 & 1029.123 & 909.525 & 22.618 \\
\hline \multicolumn{4}{|c|}{ Vegetation Volume Fraction } \\
\hline $0(\min *)$ & 1029.123 & 909.530 & 22.613 \\
\hline $0.2\left(\max ^{*}\right)$ & 1029.123 & 909.530 & 22.613 \\
\hline \multicolumn{4}{|l|}{ Surface Roughness } \\
\hline 0.15 (short, prairie) & 1029.123 & 909.530 & 22.613 \\
\hline 0.24 (dense) & 1029.123 & 909.530 & 22.613 \\
\hline 0.41 (Bermuda grass) & 1029.123 & 909.530 & 22.613 \\
\hline 0.04 (ref) & 1029.123 & 909.530 & 22.613 \\
\hline \multicolumn{4}{|l|}{ Surface Slope (\%) } \\
\hline 1 (actual data of XIFS) & 1029.123 & 909.530 & 22.613 \\
\hline 5 & 1029.123 & 909.552 & 22.591 \\
\hline 20 & 1029.123 & 909.564 & 22.579 \\
\hline \multicolumn{4}{|l|}{ Conductivity Slope $(\%)$} \\
\hline $60(\max *)$ & 1029.123 & 903.810 & 28.332 \\
\hline $30(\min *)$ & 1029.123 & 909.530 & 22.613 \\
\hline 10 (ref) & 1029.123 & 936.076 & 16.670 \\
\hline \multicolumn{4}{|c|}{ Drainage Mat Thickness (mm) } \\
\hline $25.4(\min *)$ & 1029.123 & 909.530 & 22.613 \\
\hline 38.1 & 1029.123 & 909.530 & 22.613 \\
\hline $50.8\left(\max ^{*}\right)$ & 1029.123 & 909.530 & 22.613 \\
\hline \multicolumn{4}{|l|}{ Drainage Void Fraction } \\
\hline $0.5(\min *)$ & 1029.123 & 909.534 & 22.609 \\
\hline $0.6(\max *)$ & 1029.123 & 909.530 & 22.613 \\
\hline 0.85 (ref) & 1029.123 & 909.522 & 22.622 \\
\hline \multicolumn{4}{|c|}{ Drainage Roughness Parameters } \\
\hline $0.4(\max *)$ & 1029.123 & 909.530 & 22.613 \\
\hline $0.1(\min *)$ & 1029.123 & 909.562 & 22.581 \\
\hline 0.01 (ref) & 1029.123 & 909.581 & 22.562 \\
\hline
\end{tabular}

ref: the values used by Carson et al., 2015; * max, min: the maximum and minimum data in the manual of SWMM 5.1 (USEPA, 2015).

Table 2. Reference values of 5 soil parameters for sensitivity analysis.

\begin{tabular}{cccccccc}
\hline Parameters & $\begin{array}{c}\text { Maximum } \\
\text { Data }\end{array}$ & $\begin{array}{c}\text { Minimum } \\
\text { Data }\end{array}$ & $\begin{array}{c}\text { Median } \\
\text { Data }\end{array}$ & $\begin{array}{c}\text { Average } \\
\text { Data }\end{array}$ & $\begin{array}{c}\text { Reference } \\
\text { Data }\end{array}$ & $\begin{array}{c}\text { Silt } \\
\text { Loam }\end{array}$ & $\begin{array}{c}\text { Silty } \\
\text { Clay }\end{array}$ \\
\hline $\begin{array}{c}\text { saturated hydraulic } \\
\text { conductivity (mm hr } \text { h }^{-1} \text { ) }\end{array}$ & 120.396 & 0.254 & 1.524 & 16.002 & 1.016 & 6.604 & 0.508 \\
suction head (mm) & 320.04 & 49.022 & 210.058 & 184.450 & 100.076 & 169.926 & 290.068 \\
porosity & 0.510 & 0.398 & 0.463 & 0.455 & 0.510 & 0.501 & 0.398 \\
field capacity & 0.378 & 0.062 & 0.284 & 0.258 & 0.490 & 0.244 & 0.371 \\
wilting point & 0.265 & 0.024 & 0.136 & 0.152 & 0.090 & 0.135 & 0.251 \\
\hline
\end{tabular}




\section{Evapotranspiration}

Five methods were applied to evaluate ET uncertainty and their effects on the GRS effectiveness: Hargreaves [82], Penman-Monteith [60], Pan Evaporation [60], Advection-Aridity method [83], and Granger-Gray method [84].

The first method (Hargreaves) is the default method in SWMM to compute PET $[80,85]$. However, the Hargreaves method only considers a few of the meteorological parameters such as air temperature and extraterrestrial radiation. Therefore, methods using more meteorological data are needed to calculate the values of RET and AET [60,86,87]. Furthermore, several authors [26] have highlighted that the use of Potential ET rather than Actual ET (which is influenced by the substrate moisture content) seriously limits the accuracy or retention estimations in SWMM. Therefore, the values of AET, RET, and PET are compared on the consideration of the important role of ET in the hydrodynamic process of green roofs.

The second method, Penman-Monteith approach, has more parameters than the Hargreaves approach and is a widely accepted method for calculating RET [60]. By assuming a grass reference surface, the ET calculated by the FAO Penman-Monteith equation provides a standard ET over time and space, which can be used to infer ET from other plants (i.e., those used in LID) [60].

The third method, Pan Evaporation, relates ET to a RET value by an empirically derived pan coefficient [60]. Pan coefficients vary based on the type of pan, humidity, wind, surface vegetation, and condition of the upwind buffer zone [60]. In our simulations, wind speed ranges from 2 to $5 \mathrm{~m} \mathrm{~s}^{-1}$ and the mean Relative Humidity $(\mathrm{RH})$ is about $75 \%$, so $\mathrm{K}_{\mathrm{p}}$ should range from 0.8 to 1.1 [60]. Continuous daily precipitation, Pan Evaporation data, humidity, and wind speed data covers year 2015.

The fourth method is Advection-Aridity method that was first proposed to calculate the actual regional ET [83,88].

The fifth method is Granger-Gray method that is widely applied to various surface conditions [84, $89,90]$. Both the Advection-Aridity method and the Granger-Gray method are widely used methods to calculate the AET [90].

\subsubsection{Comparison between GRS and IGRS}

The IGRS is a combination of green roof and rooftop disconnection (see Figure S1 in Supplementary Information). Instead of discharging rainwater directly into a drainage pipeline under the road, the outlets of the downspouts in IGRS are permeable greenbelts or landscape areas. Therefore, the IGRS can take excess surface runoff from the drainage layer of the green roof and transport it to the grassed lawn nearby.

Although the GRS could manage small precipitation events well, the effect will decrease greatly for large precipitation events [16]. Within a heavy precipitation, most surface runoff is discharged via the drainage layer of GRS into the CSS/SWS. As an important structure of the IGRS, rooftop disconnection can direct runoff from rooftops to grassed lawns to help to keep water away from the drainage ditches besides buildings so as to increase infiltration [91]. Application opportunities for rooftop disconnection include any location where rooftop runoff can be directed onto a vegetated area [91], such as adjacent greenbelts. This improvement has the potential to better mitigate urban flooding and recharge groundwater.

As shown in Figure $3 c$, the difference from part 1 is that the XIFS catchment was divided into five sub-catchments, and each sub-catchment $\left(S_{i}, \mathrm{i}=1,2, \ldots, 5\right)$ in part 2 was further divided into three compartments, with $B_{i}$ representing the buildings which accounts for $45 \%$ of the total area, $G_{i}$ standing for the greenbelts next to the buildings, and $\mathrm{H}_{i}$ representing the impervious ground. Therefore, $S_{i}=B_{i}+$ $G_{i}+H_{i}(i=1,2, \ldots, 5)$. Define all the $G_{i}$ parts as separate pervious sub-catchments with properties representative of the most common greenbelt on the streets of the city studied. As a result that most of the greenbelt soil texture in Nanchang is clay loam, the infiltration parameter of the greenbelt refers to the value of clay loam in the manual of SWMM 5.1. The $G_{i}$ parameters are shown in Table 3. 
Two scenarios are studied in the comparison between GRS and IGRS. In the GRS scenario, all excess runoff drained from green roofs was diverted into CSS/SWS. In this case, the greenbelts $G_{i}(i=1,2 \ldots 5)$ only collect the precipitation that directly falls on them and do not capture the runoff from other areas. In the IGRS scenario, all excess runoff drained from green roofs was diverted to greenbelts. Therefore, the greenbelts $G_{i}(i=1,2 \ldots 5)$ collect direct precipitation and the outflow runoff from green roofs $B_{i}(i=1,2 \ldots 5)$.

As a result that the width of greenbelts next to buildings is generally 1-3 $\mathrm{m}$ in China, 1-, 2-, and 3- meter widths for $G_{i}$ were used to test the effectiveness of IGRS. In addition, according to China's architectural design code, the minimum distance between two buildings is $6 \mathrm{~m}$, so it is feasible to arrange a 1-3 m wide greenbelt.

Table 3. Parameters of $G_{i}$ (greenbelt in IGRS).

\begin{tabular}{cc}
\hline Properties & Value \\
\hline pervious manning overflow & 0.15 \\
depth of the depression storage on the pervious portion of the sub-catchment $(\mathrm{mm})$ & 5.08 \\
suction head $(\mathrm{mm})$ & 210.06 \\
conductivity $\left(\mathrm{mm} \mathrm{hr}^{-1}\right)$ & 1.02 \\
initial deficit & 0.15 \\
\hline
\end{tabular}

\section{Results and Discussion}

\subsection{Single Event Simulation}

Hypothetical extensive green roofs (as mentioned in Section 2 ) are used for $\mathrm{B}_{i}(i=1,2, \ldots, 5)$. When choosing different green roofs or Bioretention cells as LID type in SWMM, the simulation shows slight differences in the amount of lid drainage and final storage obtained by but the surface runoff is consistent (Tables S1 and S2). The predicted runoff from 2-yr, 10-yr, and 100-yr precipitation events was used to evaluate the potential for surface runoff reduction.

\subsubsection{Sensitivity Analysis}

The results of sensitivity analysis show that the saturated hydraulic conductivity is the most sensitive parameter for evaporation and surface runoff; wilting point is the most sensitive parameter affecting the initial LID storage; and soil field capacity is the most sensitive parameter affecting the final storage capacity (Table 4). Based on the sensitivities of the 5 parameters and the main objective of this study to mitigate urban flooding by GRS, a combination that minimizes surface runoff was selected (Table 5). The following analyses use these substrate properties, since these parameters produced the best overall result from the sensitivity test.

Table 4. Sensitivity of 5 soil parameters.

\begin{tabular}{cccccc}
\hline Model Output & $\begin{array}{c}\text { Saturated Hydraulic } \\
\text { Conductivity }\end{array}$ & Suction Head & Porosity & Field Capacity & Wilting Point \\
\hline Runoff & 1.3010 & 0.1754 & 0.0263 & 0.0172 & 0.0107 \\
Evaporation & 0.1601 & 0.1062 & 0.0040 & 0.0032 & 0.0948 \\
Initial Storage & 0.0349 & 0.0446 & 0.5466 & 0.9182 & 1.2905 \\
Final Storage & 0.5478 & 0.2741 & 0.4078 & 0.6879 & 0.3064 \\
\hline
\end{tabular}


Table 5. Physical input parameters for the Storm Water Management Model (SWMM) modeled GRS.

\begin{tabular}{cc}
\hline Input Parameter & Value \\
\hline Soil Layer & \\
saturated hydraulic conductivity $\left(\mathrm{mm} \mathrm{hr}^{-1}\right)$ & 167.742 \\
suction head (mm) & 169.926 \\
Porosity & 0.501 \\
field capacity & 0.244 \\
wilting point & 0.135 \\
substrate thickness (mm) & 150.000 \\
conductivity slope & 30 \\
Surface layer & \\
green roof slope (\%) & 2 \\
berm height (mm) & 0 \\
surface roughness (Manning's n) & 0.41 \\
vegetation volume fraction & 0.2 \\
Drainage Mat Layer & \\
thickness (mm) & 38 \\
void fraction & 0.6 \\
roughness (Manning's n) & 0.4 \\
\hline
\end{tabular}

\subsubsection{Runoff Retention of GRS}

Figure 5 shows the comparison of simulated runoff at the condition of the TRS and GRS. The key features are summarized in Table 6. Results indicated that the GRS significantly performs better than the TRS in reducing surface runoff. The GRS has a most significant influence on reducing urban runoff for the 2-year precipitation event. The reduction in total runoff volume by the GRS decreases as precipitation intensity increases: $42 \%, 34 \%$, and $27 \%$ reductions for $2-y r$, $10-y r$, and 100-yr precipitation events, respectively. Meanwhile, we find that runoff coefficient $(\mathrm{Q} / \mathrm{P})$ of the GRS increases from $57.41 \%$ to $72.19 \%$ when the precipitation intensity changes from 2-yr storm to 100 -yr storm (Table 6), which indicated that the retention capacity of the GRS decreases with the increase of the precipitation intensity.

It is of great importance to effectively reduce the peak surface runoff since it is often accompanied by maximum erosions and local flooding [16]. Our simulation results show that the GRS could give a much higher reduction for the peak flow than the TRS in the 2-yr precipitation event. For larger precipitation events (i.e., 10-year and 100-year precipitation events), however, this effect is reduced significantly (Table 6). Additionally, we found that the GRS has little ability to postpone runoff peak timing (less than $1 \mathrm{~min}$ ) in all the assumed precipitation events (Figure 5).

As a result that ET is negligible in the single event simulation, the volume of retained stormwater is the difference between precipitation and discharged water. For the GRS, the ratios of retained to precipitation volumes under $2-\mathrm{yr}, 10-\mathrm{yr}$, and 100-yr precipitation events are $75 \%, 55 \%$, and $41 \%$, respectively. This result is consistent with some previous studies $[29,92-94]$ and indicates that there are limitations for runoff reduction by green roofs in heavy precipitation events.

Table 6. Comparison between the TRS and GRS in single event simulation.

\begin{tabular}{cccccccc}
\hline $\begin{array}{c}\text { Precipitation } \\
\text { Design }\end{array}$ & $\begin{array}{c}\text { Precipitation } \\
(\mathbf{m m})\end{array}$ & \multicolumn{2}{c}{ Runoff Volume $(\mathbf{m m})$} & \multicolumn{2}{c}{ Runoff Coeff. $(\%)$} & \multicolumn{2}{c}{ Peak Runoff $\left(\mathbf{m}^{\mathbf{3}} / \mathbf{s}\right)$} \\
\cline { 3 - 8 } & & TRS & GRS & TRS & GRS & TRS & GRS \\
\hline $2-y r$ & 30 & 29.79 & 17.32 & 98.70 & 57.41 & 2.58 & 1.77 \\
$10-y r$ & 46 & 45.84 & 30.41 & 99.10 & 65.72 & 4.02 & 3.41 \\
$100-y r$ & 70 & 70.14 & 50.97 & 99.30 & 72.19 & 6.20 & 5.70 \\
\hline
\end{tabular}




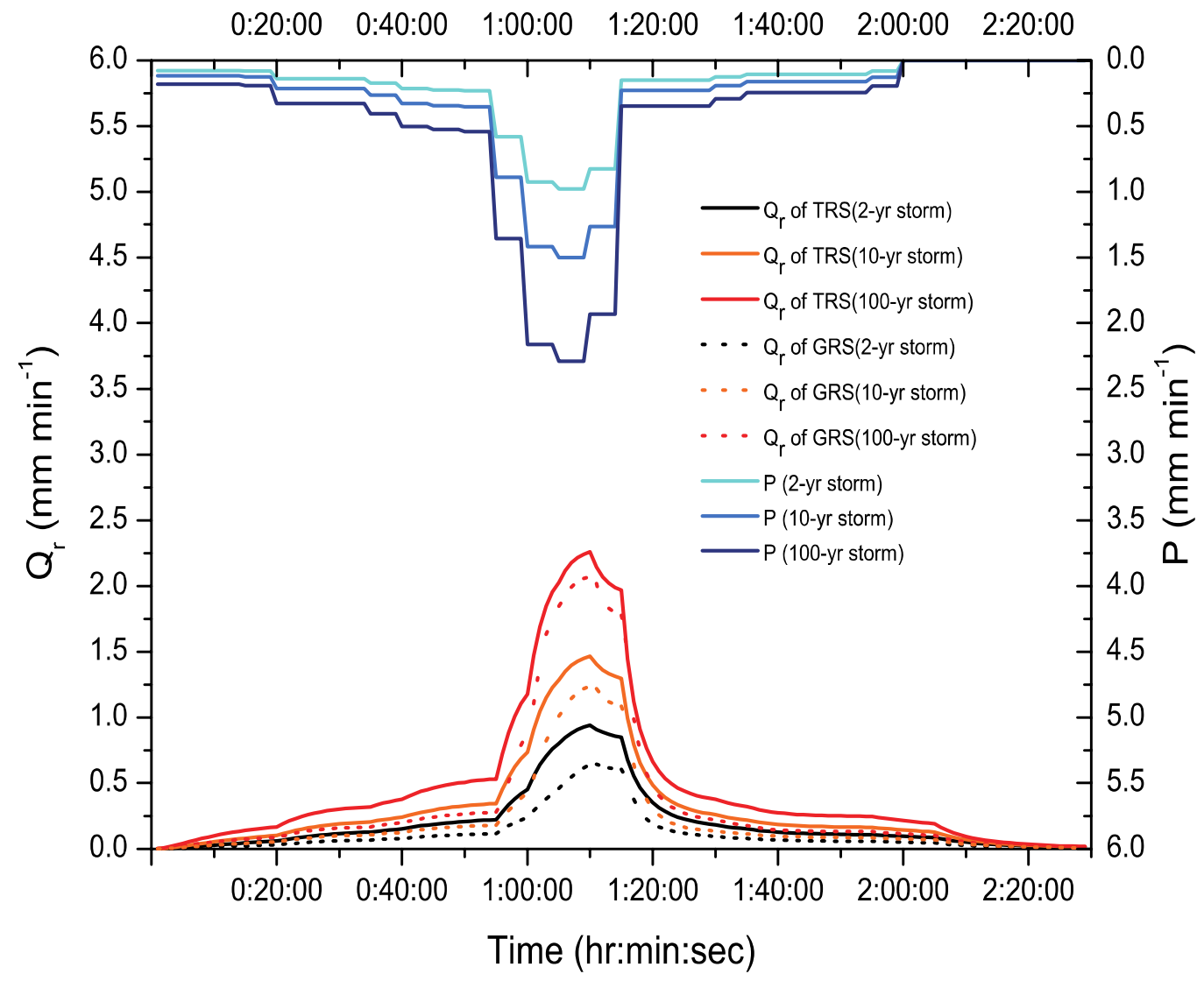

Figure 5. Comparison of runoff hydrographs between TRS and GRS for 3 single precipitation events (2-yr, 10-yr, and 100-yr). P: precipitation; $Q_{r}$ : discharge of runoff.

\subsubsection{Mitigation Conditions of Flooding Nodes and Overloaded Conduits}

The ability of the GRS to mitigate urban flooding can be shown from the amount of flood discharge generated after storm events of different intensities (Figure 6). In the 2-yr precipitation event, neither the GRS nor the TRS generate flooding (thus results were not shown in Figure 6). In the 10- and 100-yr precipitation events, however, the flooding volumes of the GRS are $82 \%$ and $28 \%$ less than those of the TRS, respectively. In addition, the peak flooding flow in the case of the GRS is significantly less than that of the TRS (Figure 6) and the peak flooding flow is 72\%, and 19\% lower than those of the TRS in the 10-yr and 100-yr precipitation events, respectively. Moreover, the drainage condition of CSS/SWS in GRS is much better than that of TRS. According to the simulations from the SWMM, in the 10-yr precipitation event, there is one flooding node (J4) and one overload conduit (C4) in the CSS/SWS of TRS (Figure 7a,c). As shown in the Figure 7c, the GRS reduces the capacity of conduit (C4) to less than 1 (1 means overloaded) and the duration and volume of flooding node (J4) in the GRS are much less than that of the TRS. In the 100-yr precipitation event, there are three flooding nodes (J2, J3, J4) and two overloaded conduits $(C 3, C 4)$ in the TRS (Figure $7 \mathrm{~b}, \mathrm{~d})$. The GRS, even in such a high intensity, still reduces the flood risk well with only one overloaded pipeline (C4) and three flooding nodes. Although there are still three flooding nodes (J2, J3, J4) in the GRS case in the 100-year events, they are significantly mitigated. 


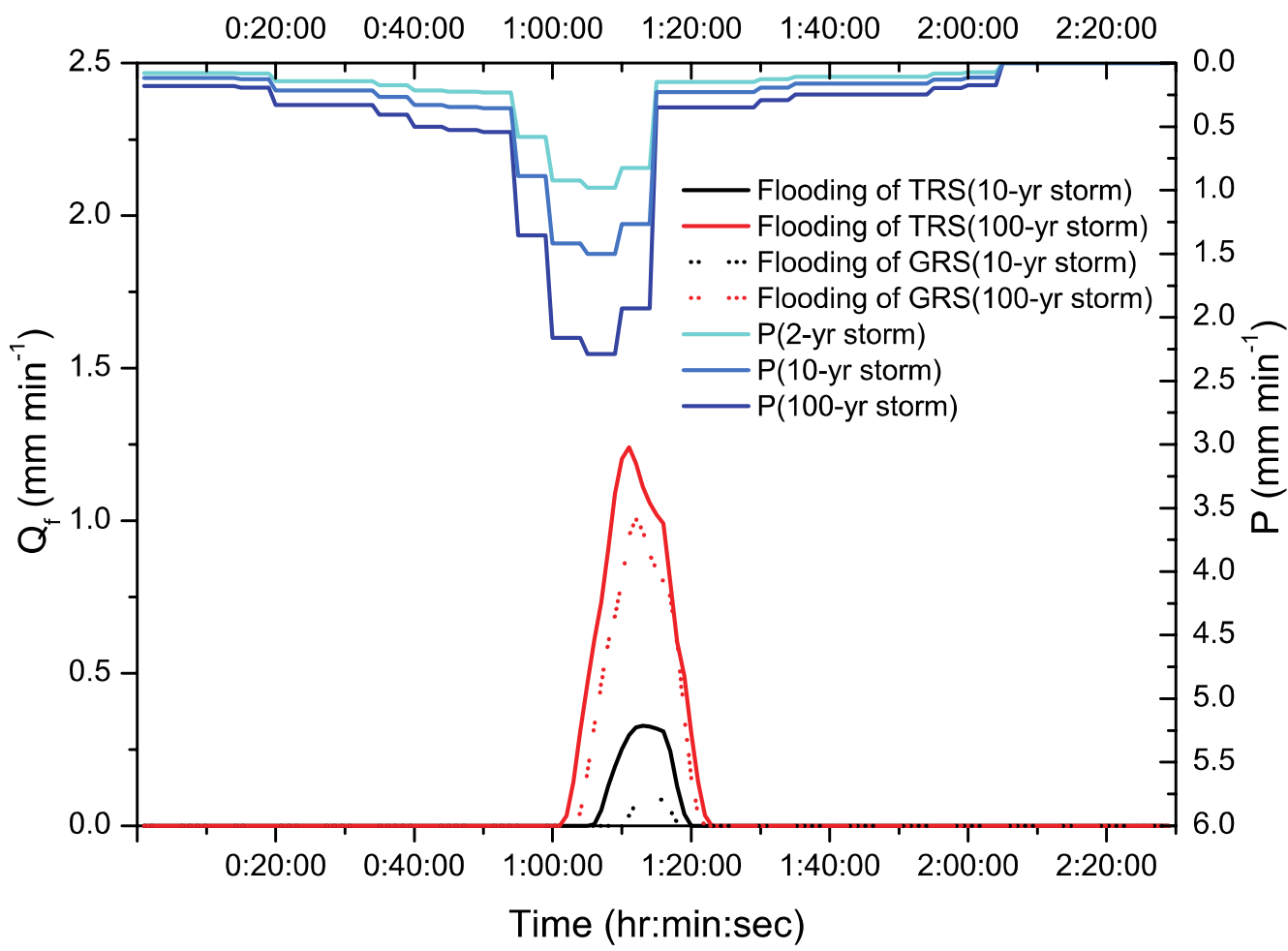

Figure 6. Comparison of flood flow between TRS and GRS for 3 single precipitation events (2-yr, 10-yr, and 100-yr). P: precipitation; $\mathrm{Q}_{\mathrm{f}}$ : discharge of flood.

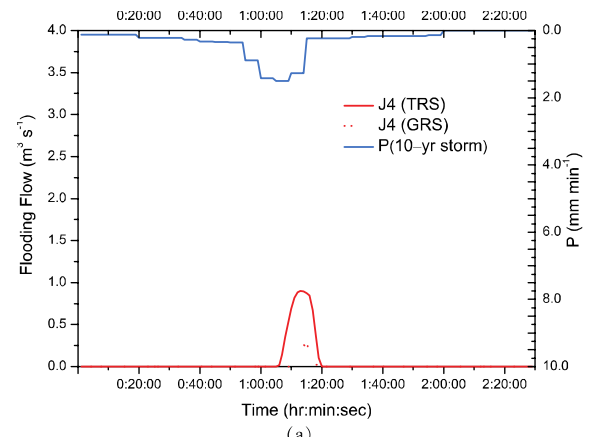

(a)



(c)

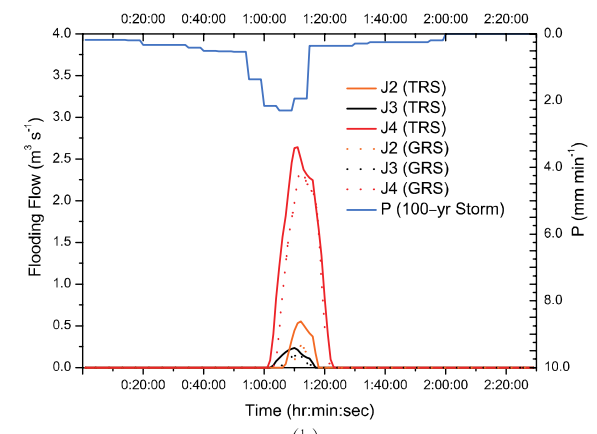

(b)

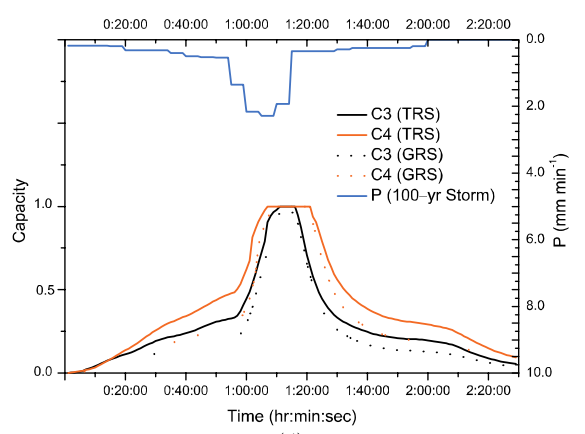

Figure 7. Comparison of hydraulic conditions between TRS and GRS for 2 single precipitation events (10-yr, and 100-yr). (a) the flooding nodes (10-yr precipitation); (b) the flooding nodes (100-yr precipitation); (c) the overloaded conduits (10-yr precipitation); (d) the overloaded conduits (100-yr precipitation). 


\subsection{Continuous Simulations}

In the continuous simulations (31-year), the change in surface runoff is consistent with that of rainfall with June as the peak month of surface runoff (Figure 8). There is a relatively high average evaporation between April and September in the GRS case. In August and September, the rainfall is relatively low (Figure 9). In addition to reducing runoff, ET can reduce urban temperatures, especially during warm months [95]. The surface runoff in the GRS case accounts for $47 \%$ of annual precipitation, while that in the TRS case accounts for $90 \%$ (Table 7).

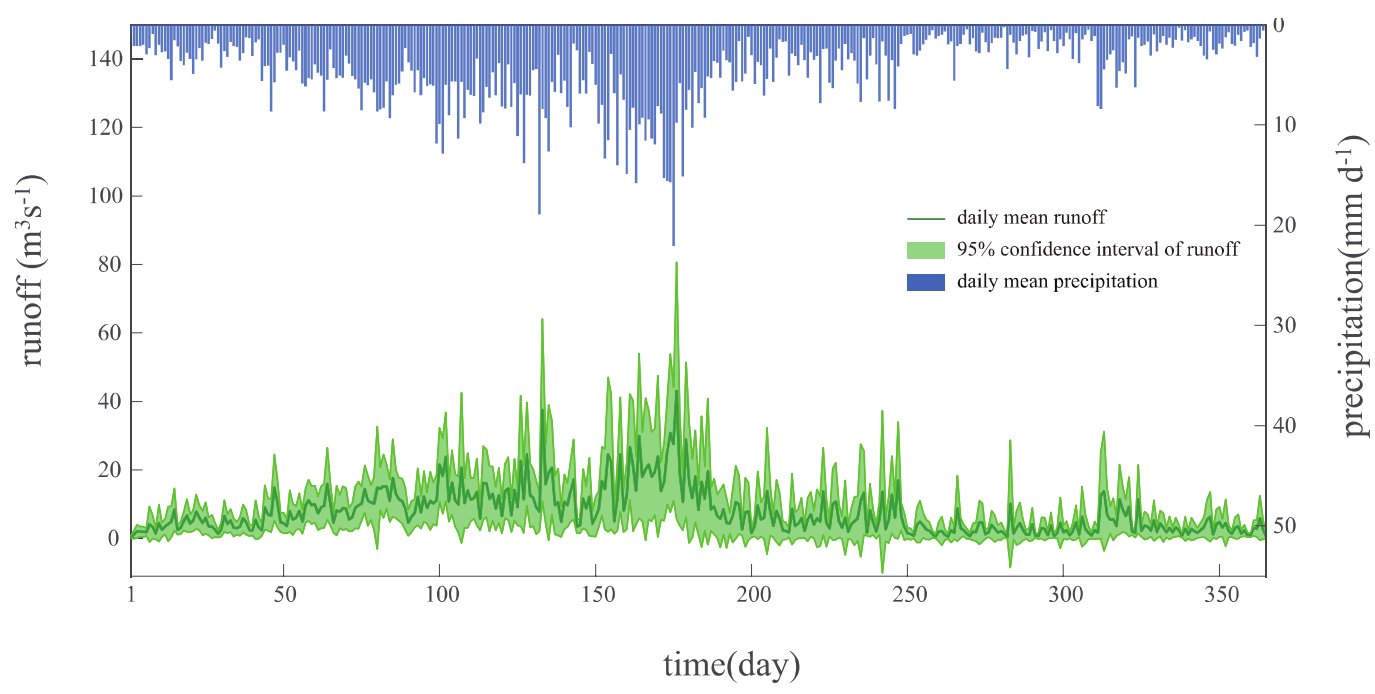

Figure 8. Daily mean GRS runoff over 31 years (1985-2015).

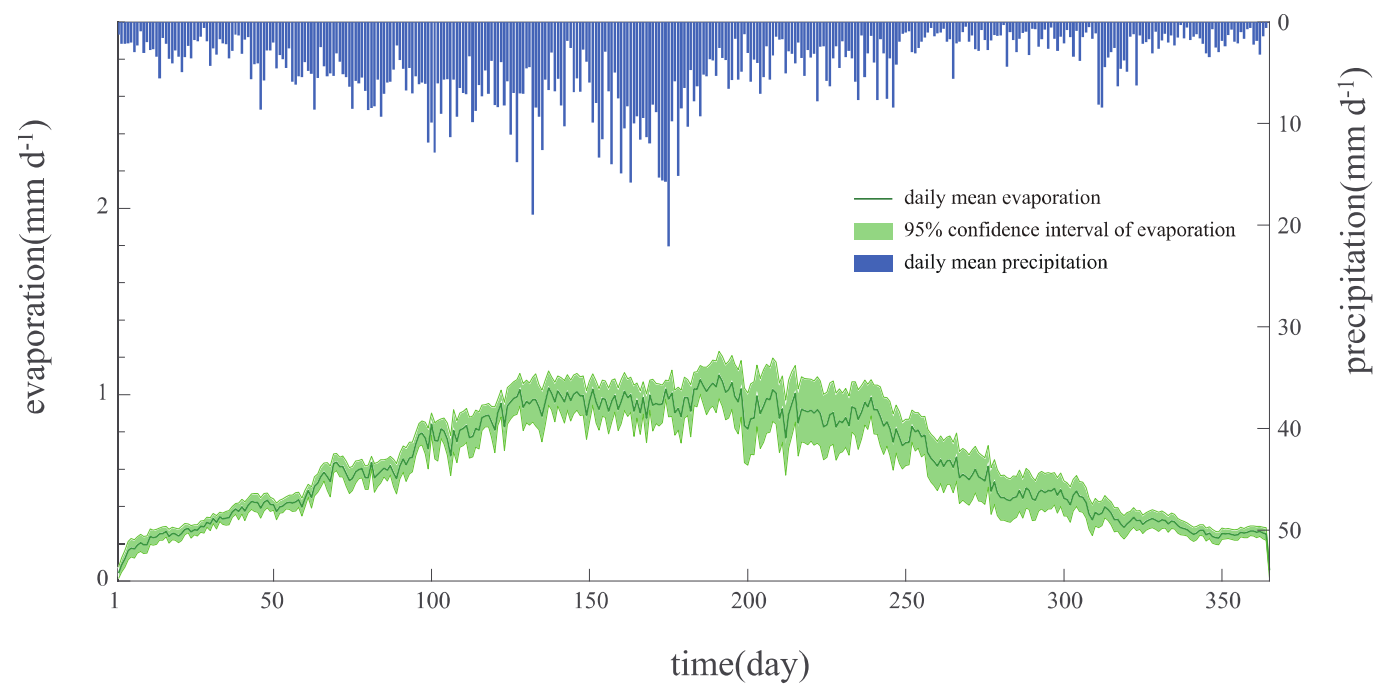

Figure 9. Daily mean GRS ET over 31 years (from 1985-2015).

Table 7. Comparison between the TRS and GRS in continuous simulation in 2015 (Unit: mm).

\begin{tabular}{ccc}
\hline Model Output & TRS & GRS \\
\hline Initial LID Storage & 0 & 10 \\
Total Precipitation & 2206 & 2206 \\
Evaporation Loss & 224 & 256 \\
Surface Runoff & 1984 & 1029 \\
LID Drainage & 0 & 910 \\
Final Storage & 0 & 23 \\
\hline
\end{tabular}


Green roofs can be beneficial to urban environment by reducing surface runoff through ET [16]. The pore space in the soil layer of green roofs, which provides space for retention, can hold water by capillary forces until water is lost via ET. Therefore, ET amount can be quantified by analyzing the moisture loss in green roofs [16]. The evaporation amounts in the GRS and TRS cases are very close (Figure 10) and account for $11.6 \%$ and $10.2 \%$ of annual precipitation, respectively. The reason could be that the evaporation values are calculated based on water balance in the SWMM, without considering the actual dynamic process. The output of Potential Evapotranspiration (PET) in the SWMM, which account for $25.2 \%$ of the annual precipitation, is calculated by Hargreaves method (Figure 10). The RET calculated based on the Penman-Monteith method and Pan Evaporation method, account for $38.6 \%$ and $37.7 \%$ total precipitation, respectively. The AET calculated by the Advection-Aridity method and Granger-Gray method, however, account for $44.9 \%$ and $36.7 \%$ of total precipitation, respectively (Figure 10). The ET values calculated based on the Penman-Monteith method, Pan Evaporation method, and Granger-Gray method are very close. They are a little smaller than the ET obtained from the Advection-Aridity method and much higher than the PET result of the Hargreaves method. Therefore, the ratio of annual ET value in the GRS to total precipitation should range from $36.7 \%$ to $38.6 \%$, which represents the rainwater retention potential of green roofs in MLRYR.

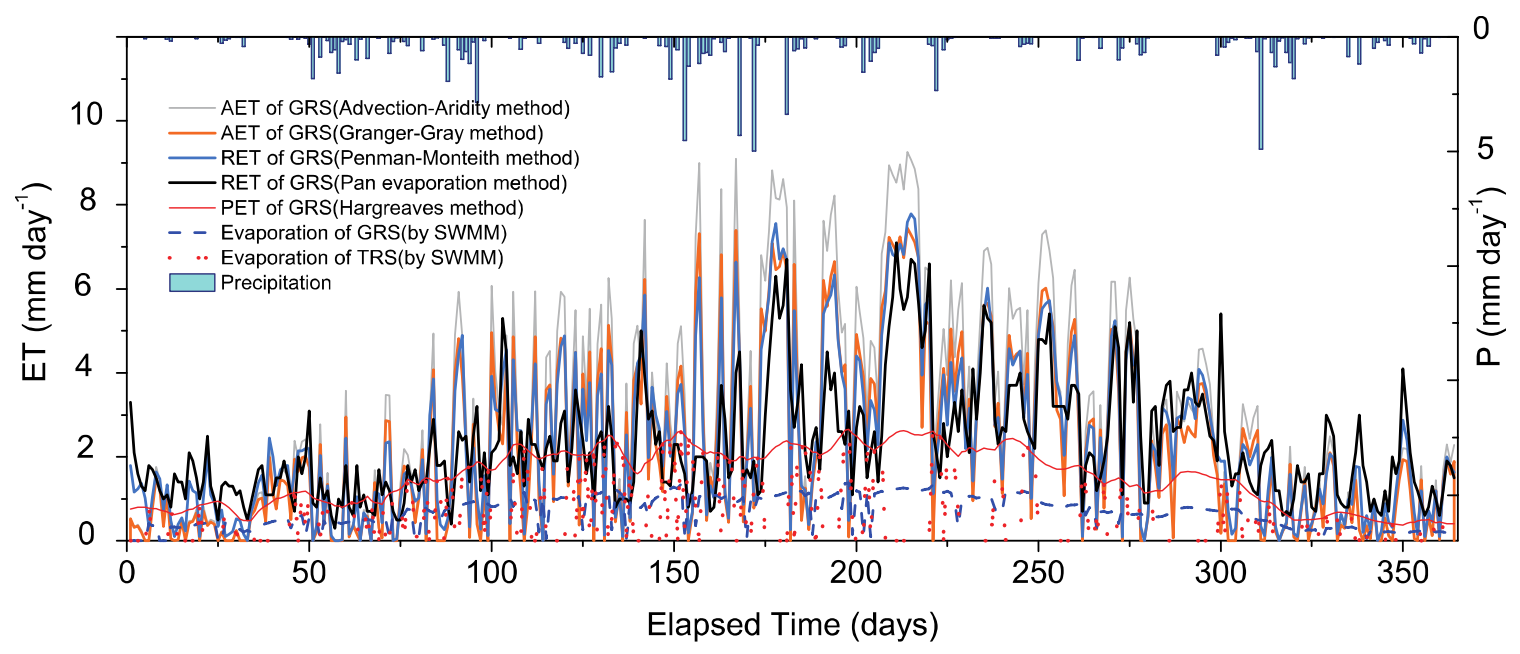

Figure 10. Daily mean GRS ET over 31 years (from 1985-2015).

In addition to the rainwater retention potential of the GRS, the evaporation curves in Figure 10 also illustrate the difference in evaporation patterns between the GRS and TRS. Although the ratio of evaporation in the GRS to that in the TRS is just 1.14:1, the timings of evaporation from GRS and TRS are quite different. In the TRS, evaporation and precipitation are concurrent. The evaporation curve is intermittent consistent with rain event timing. In the GRS, however, the rain water could be retained and evaporated between precipitation events. This result has a flaw because the evaporation result of SWMM is based on the principle of water balance. Since the TRS cannot retain water, precipitation and evaporation occur simultaneously in the time series outputs of SWMM to achieve a balance. However, in real-world the relative humidity should be very high and limit evaporation during precipitation periods. Thus, the algorithms of SWMM may be improved to adapt to the actual situation that the increased humidity suppresses the ET during heavy storms in the study region. Although there exists a drawback of the output data, the general trend of the continuous evaporation curve of the GRS implies more continuous, and likely larger, cumulative heat dissipation from the building. It thereby has potential to mitigate the urban heat island (UHI) effect. Similar results were also shown in previous researches that have evaluated green roofs' thermal benefits and suggested that GRS can reduce the UHI effect through changing roof albedo, decreasing heat transfer into buildings, decreasing long-wave radiation from leaves, evapotranspiration, and heat storage by plants [95-97]. Thus, thermal benefits could be another attractive function of green roofs if applied at the urban scale. 


\subsection{Performance of the IGRS}

The IGRS, a combined system of green roof and rooftop disconnection, has been evaluated to determine whether it is more effective at mitigating urban flooding and groundwater depletion. In the single event simulation, flooding only occurs in the cases of 10-yr and 100-yr precipitation events. The flooding volumes in the cases of GRS and IGRS are very close (Figure 11a-f, Table 8). In the 10-yr precipitation event, with the increase of greenbelt from $1 \mathrm{~m}$ to $3 \mathrm{~m}$, the flood volume in the IGRS case is $2.09-2.77 \%$ less than that in the GRS. As in the 100-yr precipitation event, with the increase of greenbelt, the flood volume in the IGRS is $0.8-1.0 \%$ less than that in the GRS. When compared with the TRS, the flooding volume in the GRS and IGRS are $67.69-71.10 \%$ and $30.13-33.22 \%$ (depending on greenbelt width) less than those of the TRS for the 10- and 100-yr precipitation events, respectively. In terms of the drainage condition of CSS/SWS, the flooding nodes (Figure 12a-f) and overloaded conduits (Figure 13a-f) in the IGRS are also consistent with the conditions in the GRS. As shown in the Figures $12 a-f$ and $13 a-f$, both the IGRS and the GRS can mitigate the flooding nodes and reduce the overloaded time of conduits when compared with the TRS, but the capacity of flood detention is slightly affected by the width of greenbelt. Results of runoff volume indicated that the differences in runoff volume and runoff coefficient $(\mathrm{Q} / \mathrm{P})$ between GRS and IGRS (Table 9) are insignificant. However, the simulated peak flows in the GRS case are 16.18-16.95\%, 25.07-25.90\%, and 28.83-29.46\% (depending on greenbelt width) lower than those in the IGRS case for the 2-yr, 10-yr, and 100-yr precipitation events, respectively (Table 9).

Table 8. Comparison of the flooding flow among the GRS, IGRS, and TRS in the single event simulation.

\begin{tabular}{ccccccc}
\hline \multirow{2}{*}{ Width } & \multicolumn{6}{c}{ Flooding Flow (mm min ${ }^{-1}$ ) } \\
\cline { 2 - 7 } & \multicolumn{2}{c}{ IGRS } & \multicolumn{2}{c}{ GRS } & \multicolumn{2}{c}{ TRS } \\
\cline { 2 - 7 } & $\mathbf{1 0 - y r}$ & $\mathbf{1 0 0}-\mathbf{y r}$ & $\mathbf{1 0 - y r}$ & $\mathbf{1 0 0}-\mathbf{y r}$ & $\mathbf{1 0 - y r}$ & $\mathbf{1 0 0}-\mathbf{y r}$ \\
\hline 1-m width greenbelt & 2.704 & 16.356 & 2.781 & 16.506 & 9.358 & 24.493 \\
2-m width greenbelt & 2.948 & 16.921 & 3.011 & 17.058 & 9.320 & 24.439 \\
3-m width greenbelt & 2.871 & 16.805 & 2.952 & 16.978 & 9.189 & 24.298 \\
\hline
\end{tabular}

Table 9. Comparison of the surface runoff between the GRS and IGRS in the single event simulation.

\begin{tabular}{|c|c|c|c|c|c|c|c|c|}
\hline \multirow[t]{2}{*}{$\begin{array}{l}\text { Precipitation } \\
\text { Design }\end{array}$} & \multirow[t]{2}{*}{$\begin{array}{c}\text { Width of } \\
\text { Greenbelt (m) }\end{array}$} & \multirow[t]{2}{*}{$\begin{array}{l}\text { Precipitation } \\
\text { (mm) }\end{array}$} & \multicolumn{2}{|c|}{$\begin{array}{l}\text { Runoff Volume } \\
\text { (mm) }\end{array}$} & \multicolumn{2}{|c|}{$\begin{array}{c}\text { Runoff Coeff. } \\
(\%)\end{array}$} & \multicolumn{2}{|c|}{$\begin{array}{l}\text { Peak Runoff } \\
\qquad\left(\mathrm{m}^{3} \mathrm{~s}^{-1}\right)\end{array}$} \\
\hline & & & GRS & IGRS & GRS & IGRS & GRS & IGRS \\
\hline \multirow[t]{3}{*}{$2 \mathrm{yr}$} & 1 & & 16.00 & 15.98 & 53.03 & 52.97 & 1.45 & 1.73 \\
\hline & 2 & 30 & 16.00 & 15.95 & 53.03 & 52.87 & 1.47 & 1.77 \\
\hline & 3 & & 15.85 & 15.80 & 52.54 & 52.37 & 1.45 & 1.74 \\
\hline \multirow[t]{3}{*}{$10-y r$} & 1 & & 28.83 & 28.78 & 62.31 & 62.20 & 2.84 & 3.79 \\
\hline & 2 & 46 & 28.88 & 28.85 & 62.42 & 62.35 & 2.88 & 3.88 \\
\hline & 3 & & 28.70 & 28.65 & 62.03 & 61.92 & 2.86 & 3.86 \\
\hline \multirow[t]{3}{*}{$100 \mathrm{yr}$} & 1 & & 49.71 & 49.73 & 70.40 & 70.43 & 5.06 & 7.11 \\
\hline & 2 & 70 & 49.73 & 49.73 & 70.43 & 70.43 & 5.13 & 7.27 \\
\hline & 3 & & 49.50 & 49.48 & 70.10 & 70.08 & 5.10 & 7.23 \\
\hline
\end{tabular}




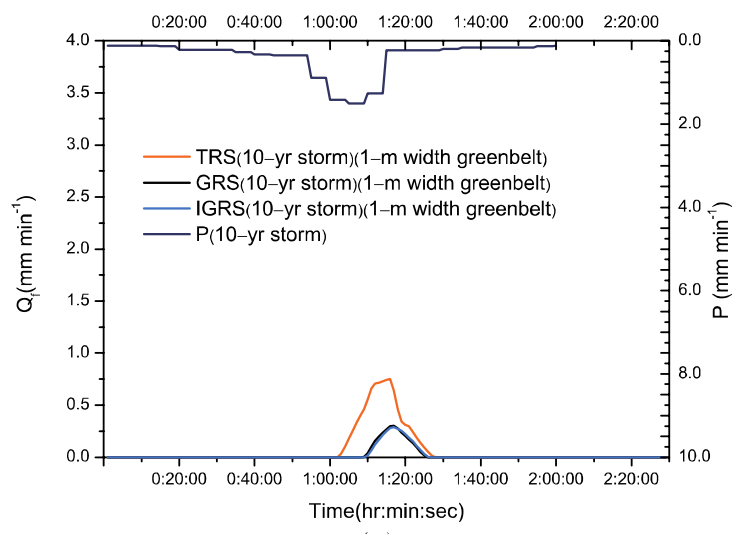

(a)

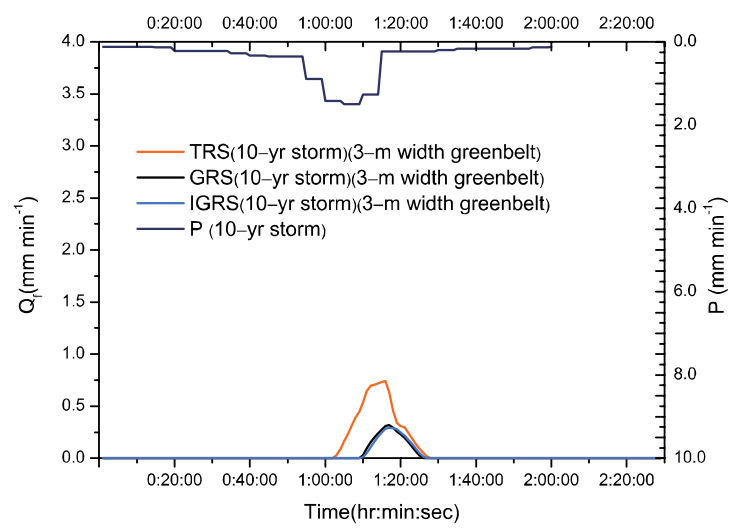

(c)

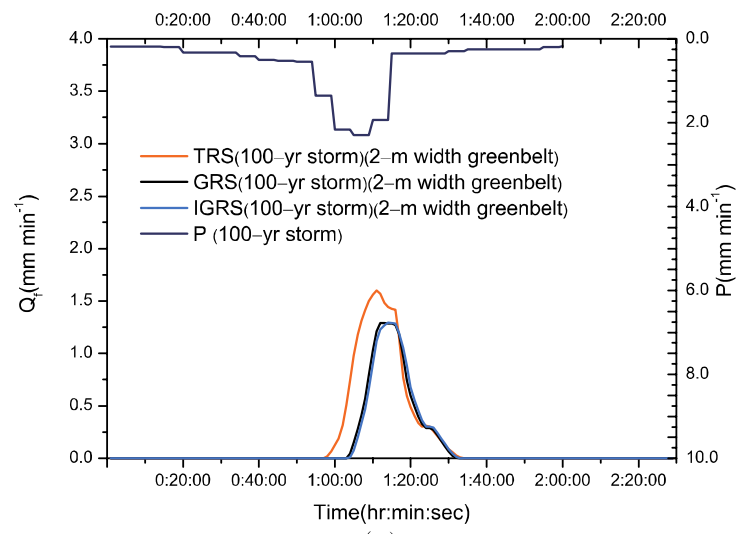

(e)

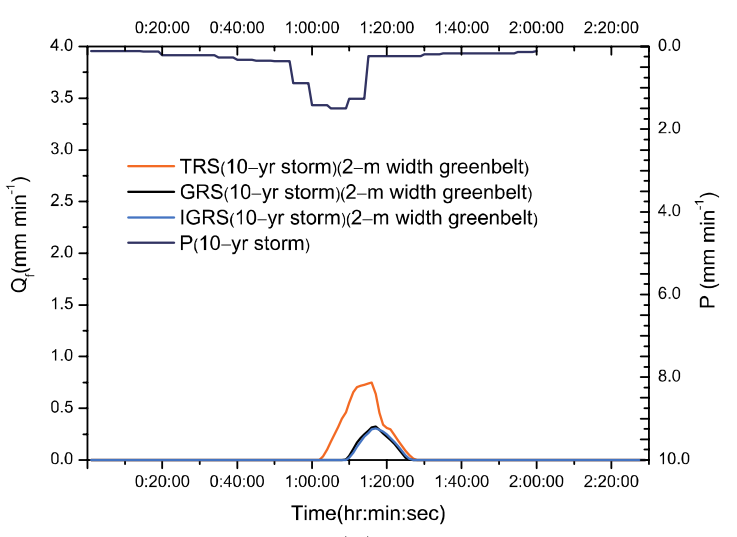

(b)

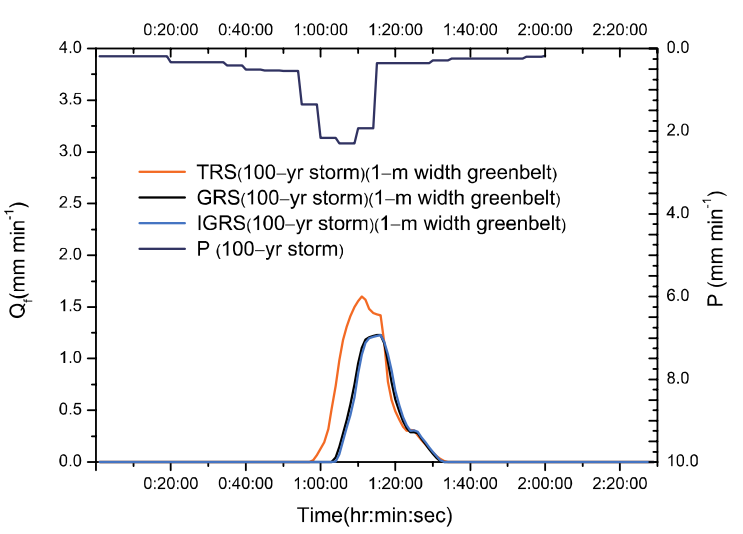

(d)

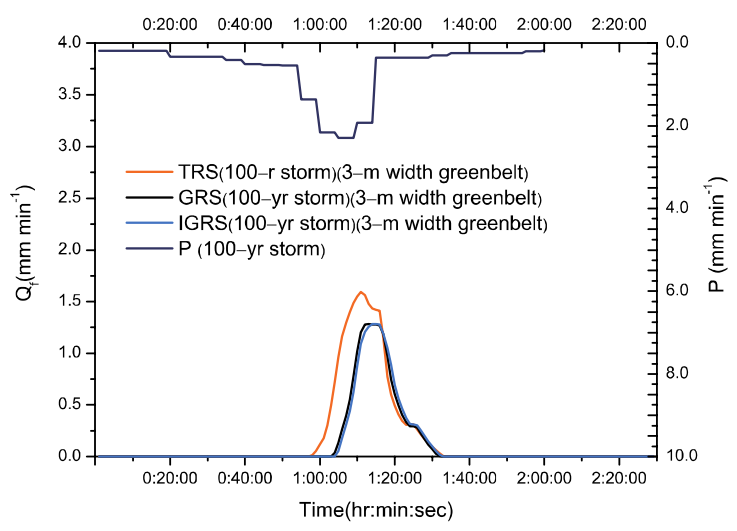

(f)

Figure 11. Comparison of flooding flow among the GRS, IGRS, and TRS for 2 single precipitation events (10-yr and 100-yr). (a) 10-yr storm (1-m width greenbelt); (b) 10-yr storm (2-m width greenbelt); (c) 10-yr storm (3-m width greenbelt); (d) 100-yr storm (1-m width greenbelt); (e) 100-yr storm (2-m width greenbelt); (f) 100-yr storm (3-m width greenbelt). 




(a)

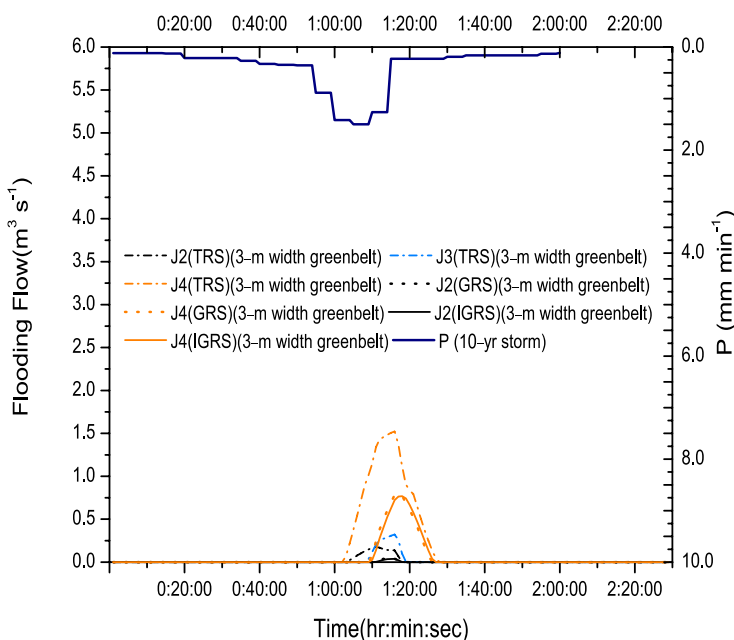

(c)

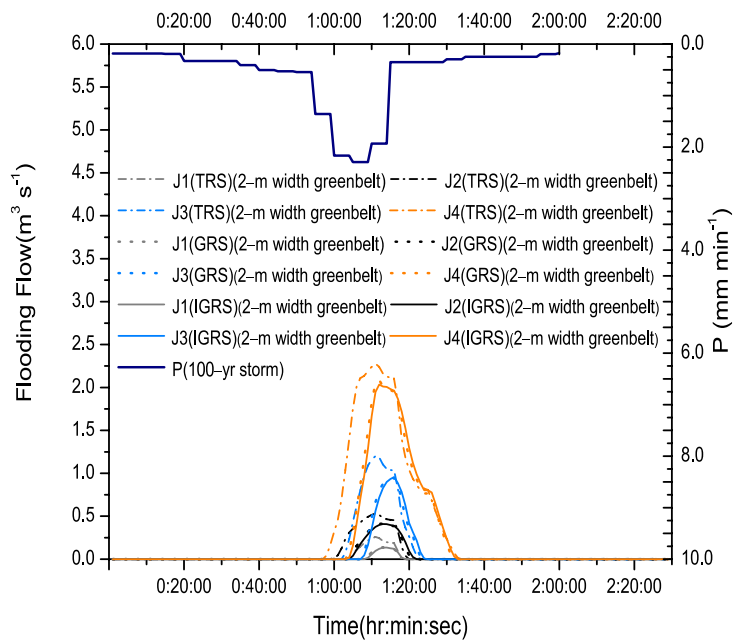

(e)

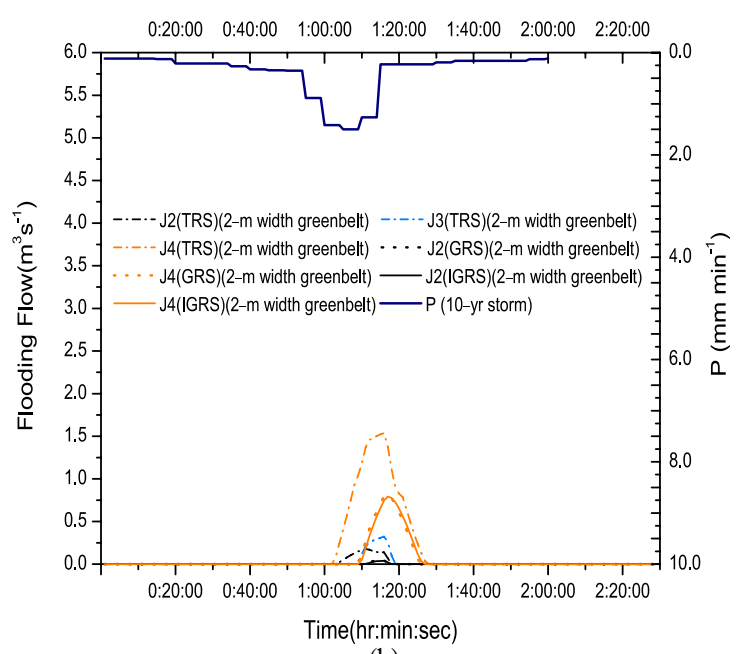

(b)

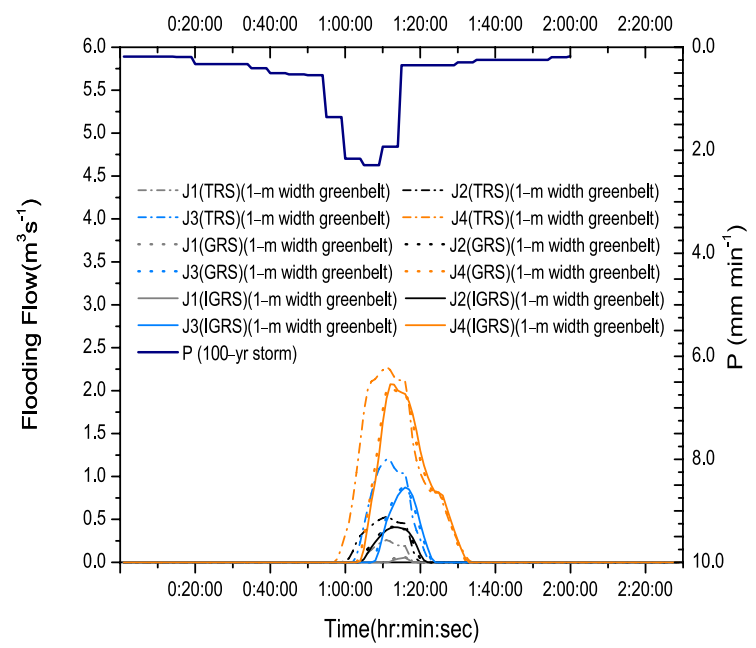

(d)

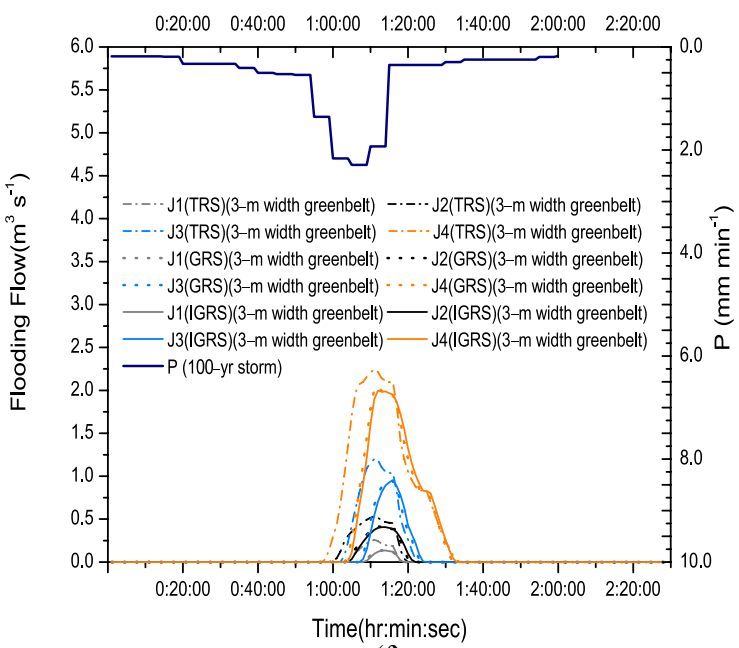

(f)

Figure 12. Comparison of the flooding nodes among the GRS, IGRS, and TRS for 2 single precipitation events (10-yr and 100-yr). (a) 10-yr storm (1-m width greenbelt); (b) 10-yr storm (2-m width greenbelt); (c) 10-yr storm (3-m width greenbelt); (d) 100-yr storm (1-m width greenbelt); (e) 100-yr storm (2-m width greenbelt); (f) 100-yr storm (3-m width greenbelt). 


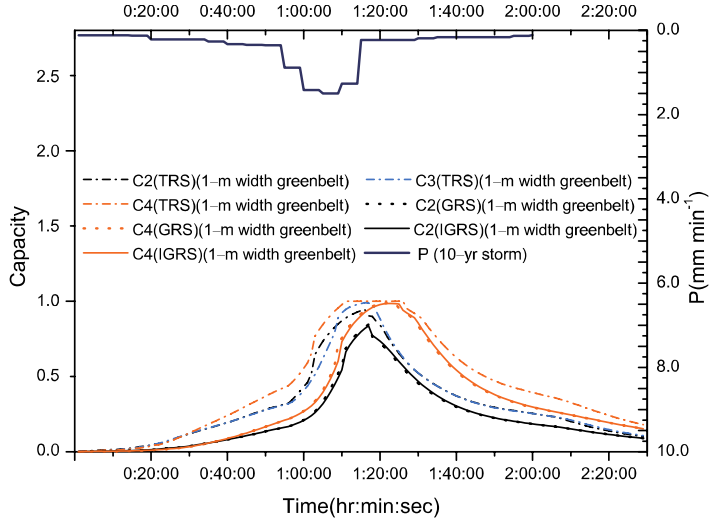

(a)

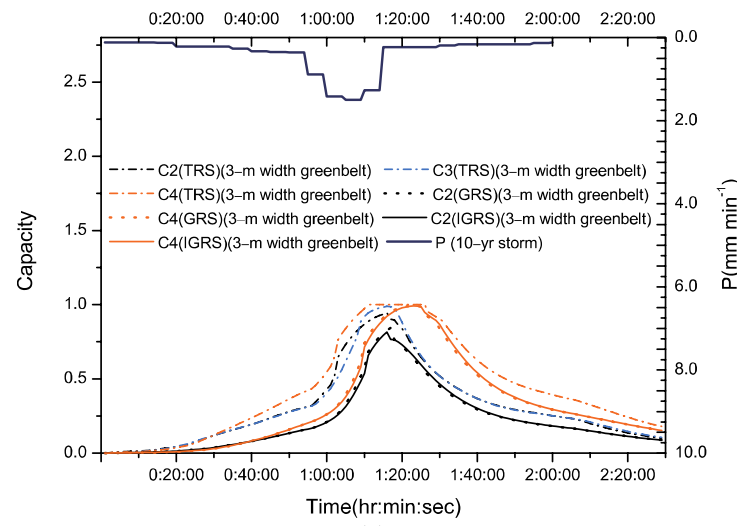

(c)

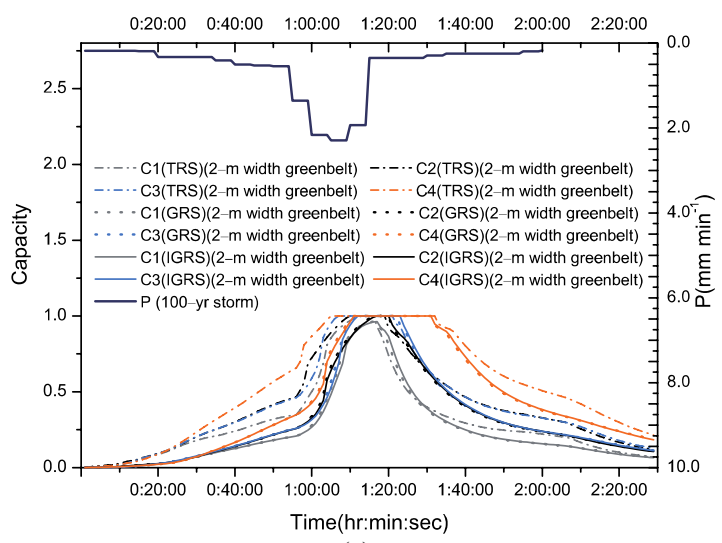

(e)

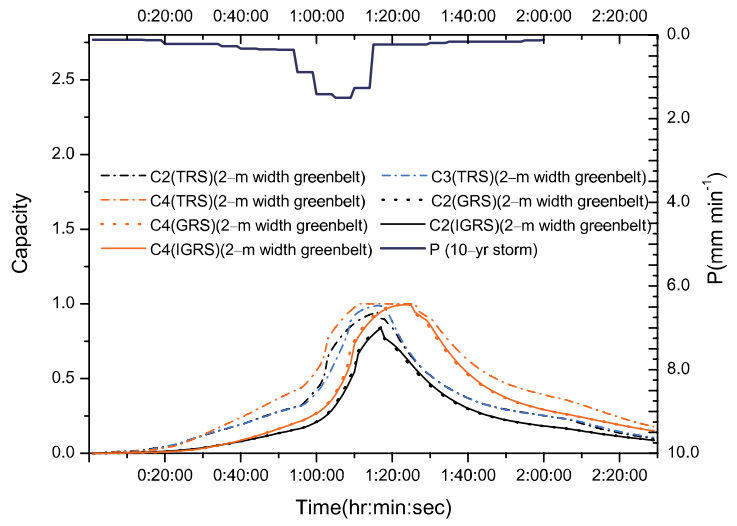

(b)

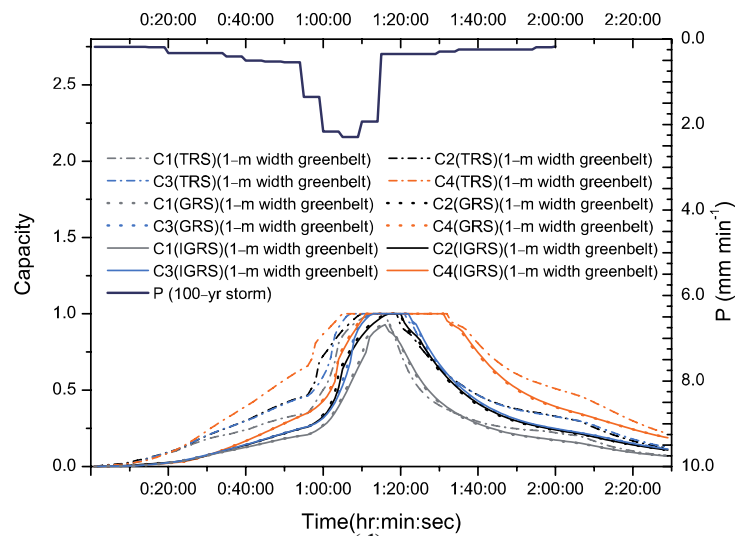

(d)



(f)

Figure 13. Comparison of the overload conduits among the GRS, IGRS, and TRS for 2 single precipitation events (10-yr and 100-yr). (a) 10-yr storm (1-m width greenbelt); (b) 10-yr storm (2-m width greenbelt); (c) 10-yr storm (3-m width greenbelt); (d) 100-yr storm (1-m width greenbelt); (e) 100-yr storm (2-m width greenbelt); (f) 100-yr storm (3-m width greenbelt).

In the continuous simulation, evaporation, surface runoff, and infiltration are three key parameters to evaluate the effect of the systems on retaining stormwater. In the same precipitation event, evaporation in the IGRS is $0.4 \%$ more than that in the GRS (Table 10). Although the surface runoff in the case of GRS is $20-27 \%$ less than that in the IGRS case, the overflowing water from GRS is drained into the CSS/SWS, which increases the burden on the CSS/SWS and does not recharge groundwater. In the IGRS case, however, the overflowing water was diverted from green roofs to infiltrate in greenbelts and recharge groundwater, which could thereby reduce the burden on the CSS/SWS. As a result, infiltration is the most important measure of the IGRS effectiveness. The proportions of infiltrated water from annual precipitation are shown in 3 categories based on the belt widths (i.e., $1 \mathrm{~m}, 2 \mathrm{~m}$, 
and $3 \mathrm{~m}$; see Figure S2). For $1 \mathrm{~m}, 2 \mathrm{~m}$, and $3 \mathrm{~m}$ greenbelts, the infiltration of IGRS accounted for 10\%, $16 \%$, and $19 \%$ of annual precipitation respectively, while that of GRS was only $0.36 \%, 0.73 \%$, and $1.09 \%$. With the 3 different greenbelt widths, IGRS would recharge to groundwater with total runoff volumes of 2126, 3273, and $4033 \mathrm{~m}^{3} \mathrm{ha}^{-1} \mathrm{yr}^{-1}$ more than with GRS.

Table 10. Comparison of the GRS and IGRS in continuous simulation in 2015.

\begin{tabular}{ccccccc}
\hline & \multicolumn{2}{c}{$\begin{array}{c}\text { 1-m Width } \\
\text { Greenbelt }\end{array}$} & \multicolumn{2}{c}{$\begin{array}{c}\text { 2-m Width } \\
\text { Greenbelt }\end{array}$} & \multicolumn{2}{c}{$\begin{array}{c}\text { 3-m Width } \\
\text { Greenbelt }\end{array}$} \\
\hline Depth (mm) & GRS & IGRS & GRS & IGRS & GRS & IGRS \\
\hline Initial LID Storage & 9 & 9 & 9 & 9 & 9 & 9 \\
Total Precipitation & 2206 & 2206 & 2206 & 2206 & 2206 & 2206 \\
Evaporation Loss & 234 & 235 & 233 & 234 & 232 & 233 \\
Infiltration Loss & 8 & 221 & 16 & 343 & 24 & 428 \\
Surface Runoff & 1069 & 1738 & 1062 & 1617 & 1055 & 1533 \\
LID Drainage & 883 & 0 & 883 & 0 & 883 & 0 \\
Final Storage & 21 & 21 & 21 & 21 & 21 & 21 \\
\hline
\end{tabular}

Although IGRS is not as efficient as GRS in controlling surface runoff in both short-term and continuous simulation, it may have great potential if engineering design is carried out in practice. If some drainage pipes with a small diameter are used to quickly introduce rainwater into different depths of soil layer under the greenbelt, the efficiency of surface runoff control will be greatly improved. Compared with the situation that GRS introduces roof rainwater into the full flow drainage pipe during a heavy storm, IGRS will lead rainwater to different depths of the soil, which plays a good role in diverting rainwater. Furthermore, IGRS can reduce water consumption for municipal greening. Therefore, IGRS has the value of further experimental research and application from the aspects of groundwater recharge, municipal greening water reduction, and surface runoff reduction.

The XIFS is a representative of the whole city because of the homogeneous climate condition (precipitation, solar radiation, wind, etc.) and the consistent planning standard for building density and floor area ratio according to the Urban Planning of Nanchang City. Therefore, we can project the simulated results from this study site to most areas of the city if not all. Assuming that the IGRS is widely used in the city, the total estimated runoff that can recharge groundwater would be beneficial to mitigate urban drought and groundwater depletion problems in the city. According to the comparison of infiltration ratio between GRS and IGRS (Figure S3), although not as good as GRS in controlling surface runoff, the IGRS can substantially enhance groundwater recharge. In the whole city, the GRS and IGRS can be used in different areas according to their own characteristics. Particularly, the GRS can be adopted in the areas where CSS/SWS capacity is insufficient to cope with large peak runoff because the peak runoff of GRS is 16-29\% less than that of IGRS and can be used as an effective way to reduce surface runoff. In places where the capacity of CSS/SWS is large enough to deal with surface runoff, the IGRS can be used as an innovative way to make full use of the rich rainwater resources in Nanchang to recharge groundwater since urban flooding is not a threat in these places. The cities in the MLRYR are generally densely built areas that have a large potential to be retrofitted with GRS and IGRS.

\section{Conclusions}

Our results suggest that green roof installation on existing roofs in Nanchang could provide buffer water storage that can reduce peak runoff flow rates during extreme rainfall events. Thus, effectively mitigate urban flooding. It also enhances ET and thereby reduces longer term cumulative runoff volumes. These two phenomena have been modeled using respectively 2-hour and long-term timescales. Both will influence the likelihood of flooding. The numerical simulations indicate that the GRS can be more effective than the TRS for managing precipitation events. On a single event basis, a GRS is better 
at reducing surface runoff and peak flow for a 2-yr precipitation event than for the heavier 10-yr and 100 -yr precipitation events. The reduction in runoff volume between the TRS and GRS decreases as precipitation intensity increases: $42 \%, 34 \%$, and $27 \%$ reductions for $2-y r, 10-y r$, and 100-yr precipitation events, respectively. Peak flow in the GRS decreased by $31 \%, 15 \%$, and $8 \%$ compared with those in the TRS for 2-yr, 10-yr, and 100-yr precipitation events, respectively. There is effectively no time lag ( 1 min) between the surface runoff peaks from TRS and GRS for the same precipitation event. Furthermore, not only the flood volume of GRS reduced by $82 \%$ and $28 \%$ compared with TRS in 10-year and 100-year precipitation event as well as the peak flood flow decreased by $72 \%$ and $19 \%$, the hydraulic conditions of GRS is also better than TRS by reducing the overflow volume and the flooding period of nodes and conduits. Considering that MLRYR is one of the most densely populated areas in China, for example the population density of Nanchang city, which is only belong to second-tier cities in MLRYR, is almost 16,000 people per kilometer, GRS is a feasible option because it does not require additional urban land.

We showed by using continuous simulations that ET, which is affected by local climatic factors, plays a crucial role in determining runoff reduction from green roof application. The Penman-Monteith, Pan Evaporation methods, and the Granger-Gray method were consistent in predicting that ET accounts for $\sim 39 \%$ of total precipitation in a GRS. We found that the default Hargreaves method in the SWMM predicted a significantly smaller loss via ET (i.e., $26 \%$ of total precipitation) and the evaporation output from the SWMM is only $\sim 12 \%$ of total precipitation. The potential of GRS in Nanchang was partly due to the high (39\%) proportion of precipitation lost via ET.

The simulations demonstrate that the enhanced IGRS infiltration accounts for 10-19\% of precipitation (depending on greenbelt width), which was significantly higher than that for GRS $(\sim 1 \%)$. Whether it can directly influence groundwater replenishment needs to be studied by experiment in the future. Although the efficiency of controlling surface runoff is lower than that in the GRS, the IGRS may have great potential if other urban infrastructure modifications are made so that IGRS can recharge groundwater and divert rainwater to reduce the pressure on the CSS/SWS in heavy storm. Furthermore, IGRS may provide more hydrological benefits than the GRS for municipal greening.

Our results suggest that the GRS and the IGRS can be used in different areas depending on whether the primary demand of each urban area is to mitigate urban flooding or recharge groundwater. The simulation of the hydrological processes associated with the GRS and the IGRS under local climate conditions could productively be applied in other densely developed cities in MLRYR.

Supplementary Materials: The following are available online at http://www.mdpi.com/2073-4441/12/8/2082/s1, Figure S1: The Proportion of Missing Data in the Total Precipitation Data per Year. Figure S2: Diagram of IGRS. Figure S3: Comparison of Infiltration Ratio between GRS and IGRS. Table S1: Comparison between Green Roof Type and Bioretention Cell Type in Single Event Simulation. Table S2: Comparison between Green Roof Type and Bioretention Cell Type in Continuous Simulation in 2015.

Author Contributions: Conceptualization, W.J.R. and J.N.; methodology, J.N.; software, L.L.; validation, L.S., L.L. and J.N.; formal analysis, L.S.; investigation, L.L.; resources, L.L.; data curation, L.L.; writing-original draft preparation, L.L.; writing-review and editing, J.N. and W.J.R.; visualization, L.L. and L.S; supervision, W.J.R.; project administration, W.J.R.; funding acquisition, W.J.R. and J.N. All authors have read and agreed to the published version of the manuscript.

Funding: L.S. and J.N. were partially supported by National Natural Science Foundation of China, grant number 41972244, NSF project of Guangdong, China under Contract 2018A030313165, and the Fundamental Research Funds for the Central Universities of China, grant number 11618340. L.L. was supported by National Young Scholar Training fund from China Scholarship Council. W.J.R. was supported by the U.S. Department of Energy, Office of Science, Office of Biological and Environmental Research under Contract No. DE-AC02-05CH11231 to Lawrence Berkeley National Laboratory.

Conflicts of Interest: The authors declare no conflict of interest.

Data Availability Statement: The data that support the findings of this study are available from the corresponding author upon reasonable request. 


\section{References}

1. Berndtsson, J.C. Green roof performance towards management of runoff water quantity and quality: A review. Ecol. Eng. 2010, 36, 351-360. [CrossRef]

2. Chen, C.F. Performance evaluation and development strategies for green roofs in Taiwan: A review. Ecol. Eng. 2013, 52, 51-58. [CrossRef]

3. Bianchini, F.; Hewage, K. How "green" are the green roofs? Lifecycle analysis of green roof materials. Build. Environ. 2012, 48, 57-65. [CrossRef]

4. Li, S.P.; Hou, W.; Feng, T.C. Decadal Variation of Summer Dryness/Wetness over the Middle and Lower Reaches of the Yangtze River and the Evolution of Atmospheric Circulation in the Last 52 Years. Chin. J. Atmos. Sci. 2015, 39, 885-900. (In Chinese)

5. Feng, G.L.; Yang, H.W.; Zhang, S.X.; Wang, K.; Shen, B.Z. A preliminary research on the reason of a sharp turn from drought to flood in the middle and lower reaches of the Yangtze River in late spring and early summer of 2011. Chin. J. Atmos. Sci. 2012, 36, 1009-1026. (In Chinese)

6. Wang, W.; Xu, Z.L.; Cai, X.J.; Gao, J. Aridity Characteristic in Middle and Lower Reaches of Yangtze River Area based on Paimer Drought Severity Index Analysis. Plateau Meteorol. 2016, 35, 693-707. (In Chinese)

7. Wang, Y.Q.; Zhou, L. Observed trends in extreme precipitation events in China during 1961-2001 and the associated changes in large-scale circulation. Geophys. Res. Lett. 2005, 32, 982. [CrossRef]

8. Ye, D.Z.; Huang, R.H. Advances, results and problems of the project "investigation on laws, causes and predictions of droughts and floods in the Yellow River valley and the Yangtze River valley of China". Adv. Earth Sci. 1991, 6, 24-29. (In Chinese)

9. Zhang, Q.; Xu, C.Y.; Zhang, Z.; Chen, Y.D.; Liu, C.L.; Lin, H. Spatial and temporal variability of precipitation maxima during 1960-2005 in the Yangtze River basin and possible association with large-scale circulation. J. Hydrol. 2008, 353, 215-227. [CrossRef]

10. Wang, S.P.; Zhang, C.J.; Li, Y.H.; Feng, J.Y.; Wang, J.S. Analysis of Multi-timescale Drought Variation based on Standardized Precipitation Index in China during 1960-2011. J. Desert Res. 2014, 34, 827-834. (In Chinese)

11. Liu, J.G. A Comparative analysis of current severe drought in the middle and lower reaches of Yangtze River 2011 with historical drought records. China Flood Drought Manag. 2017, 27, 46-50. (In Chinese)

12. Carson, T.; Keeley, M.; Marasco, E.D.; McGillis, W.; Culligan, P. Assessing methods for predicting green roof rainfall capture: A comparison between full-scale observations and four hydrologic models. Urban Water J. 2015, 25, 1-15. [CrossRef]

13. Cipolla, S.S.; Maglionico, M.; Stojkov, I. A long-term hydrological modelling of an extensive green roof by means of SWMM. Ecol. Eng. 2016, 95, 876-887. [CrossRef]

14. Claudia, L.; Wellington, M.; Luciene, P.S. Hydrological performance of modular-tray green roof systems for increasing the resilience of mega-cities to climate change. J. Hydrol. 2019, 573, 1057-1066.

15. Sims, A.W.; Robinson, E.C.; Smart, C.C.; Voogt, J.A.; Hay, G.J.; Lundholm, J.T.; Powers, B.; O'Carroll, D.M. Retention performance of green roofs in three different climate regions. J. Hydrol. 2016, 542, 115-124. [CrossRef]

16. Li, Y.; Babcock, R.W. Green roof hydrologic performance and modeling: A review. Water Sci. Technol. 2014, 69, 727-738. [CrossRef]

17. Dunnett, N.; Kingsbury, N. Planting Green Roofs and Living Walls; Timber Press: Portland, OR, USA, 2004.

18. Mentens, J.; Raes, D.; Hermy, M. Green roofs as a tool for solving the rainwater runoff problem in the urbanized 21st century? Landsc. Urban Plan. 2006, 77, 217-226. [CrossRef]

19. Liu, W.; Feng, Q.; Chen, W.P.; Wei, W.; Si, J.H.; Xi, H.Y. Runoff retention assessment for extensive green roofs and prioritization of structural factors at runoff plot scale using the Taguchi method. Ecol. Eng. 2019, 138, 281-288. [CrossRef]

20. Simmons, M.T.; Gardiner, B.; Windhager, S.; Tinsley, J. Green roofs are not created equal: The hydrologic and thermal performance of six different extensive green roofs and reflective and non-reflective roofs in a sub-tropical climate. Urban Ecosyst. 2008, 11, 339-348. [CrossRef]

21. Hilten, R.N.; Lawrence, T.M.; Tollner, W.E. Modeling stormwater runoff from green roofs with HYDRUS-1D. J. Hydrol. 2008, 358, 288-293. [CrossRef]

22. Talebi, A.; Bagg, S.; Sleep, E.B.; O'Carroll, M.D. Water retention performance of green roof technology: A comparison of canadian climates. Ecol. Eng. 2019, 126, 1-15. [CrossRef] 
23. Carter, T.; Jackson, C.R. Vegetated roofs for stormwater management at multiple spatial scales. Landsc. Urban Plan. 2007, 80, 84-94. [CrossRef]

24. Bollman, A.M.; Desantis, E.G.; DuChanois, M.R.; Etten-Bohm, M.; Olszyk, M.D.; Lambrinos, G.J.; Mayer, M.P. A framework for optimizing hydrologic performance of green roof media. Ecol. Eng. 2019, 140, 1-10. [CrossRef] [PubMed]

25. Feitosa, R.C.; Wilkinson, S. Modelling green roof stormwater response for different soil depths. Landsc. Urban Plan. 2016, 153, 170-179. [CrossRef]

26. Peng, Z.; Smith, C.; Stovin, V. Internal fluctuations in green roof substrate moisture content during storm events: Monitored data and model simulations. J. Hydrol. 2019, 573, 872-884. [CrossRef]

27. Voyde, E.; Fassman, E.; Simcock, R. Hydrology of an extensive living roof under sub-tropical climate conditions in Auckland, New Zealand. J. Hydrol. 2010, 394, 384-395. [CrossRef]

28. Yio, M.H.N.; Stovin, V.; Werdin, J.; Vesuviano, G. Experimental analysis of green roof substrate detention characteristics. Water Sci. Technol. 2013, 68, 1477-1486. [CrossRef]

29. VanWoert, N.D.; Rowe, D.B.; Andresen, J.A.; Rugh, C.L.; Fernandez, R.T.; Xiao, L. Green roof stormwater retention: Effects of roof surface, slope, and media depth. J. Environ. Qual. 2005, 34, 1036-1044. [CrossRef]

30. Yang, J.C.; Bou-Zeid, E. Scale dependence of the benefits and efficiency of green and cool roofs. Landsc. Urban Plan. 2019, 185, 127-140. [CrossRef]

31. Du, P.Z.; Arndt, K.S.; Farrell, C. Is plant survival on green roofs related to their drought response, water use or climate of origin? Sci. Total Environ. 2019, 667, 25-32. [CrossRef]

32. Schroder, R.; Mohri, M.; Kiehl, K. AMF inoculation of green roof substrate improves plant performance but reduces drought resistance of native dry grassland species. Ecol. Eng. 2019, 139, 1-9. [CrossRef]

33. Tran, S.; Lundholm, T.J.; Staniec, M.; Robinson, E.C.; Smart, C.C.; Voogt, A.J.; O'Carroll, M.D. Plant survival and growth on extensive green roofs: A distributed T experiment in three climate regions. Ecol. Eng. 2019, 127, 494-503. [CrossRef]

34. Wong, G.K.; Jim, C. Quantitative hydrologic performance of extensive green roof under humid-tropical rainfall regime. Ecol. Eng. 2014, 70, 366-378. [CrossRef]

35. Liu, W.; Feng, Q.; Cheng, W.P.; Wei, W.; Deo, C.R. The influence of structural factors on stormwater runoff retention of extensive green roofs: New evidence from scale-based models and real experiments. J. Hydrol. 2019, 569, 230-238. [CrossRef]

36. Metselaar, K. Water retention and evapotranspiration of green roofs and possible natural vegetation types. Resour. Conserv. Recycl. 2012, 64, 49-55. [CrossRef]

37. Sendo, T.; Kanechi, M.; Uno, Y.; Inagaki, N. Evaluation of growth and green coverage of ten ornamental species for planting as urban rooftop greening. J. Jpn. Soc. Hortic. Sci. 2010, 79, 69-76. [CrossRef]

38. Xiao, M.; Lin, Y.L.; Han, J.; Zhang, G. A review of green roof research and development in China. Renew. Sustain. Energy Rev. 2014, 40, 633-648. [CrossRef]

39. Li, Z.L.; Chou, D.H.C.; Yao, J.; Zheng, X.; Zhao, W.; Zhilei, L.; Dhc, C.; Jian, Y.; Xiao, Z.; Wei, Z. The effectiveness of adding horizontal greening and vertical greening to courtyard areas of existing buildings in the hot summer cold winter region of China: A case study for Ningbo. Energy Build. 2019, 196, 227-239. [CrossRef]

40. Jiang, C.X. Roof greening practice of Minhang district of Shanghai. Chin. Landsc. Archit. 2011, 8, 92-95.

41. Liu, Z.F.; Chen, C. A study on the application of low impact development of green roof in large underground buildings based on SWMM. J. Nanjing For. Univ. (Nat. Sci. Ed.) 2018, 42, 165-173.

42. Li, S.X.; Qin, H.P.; Peng, Y.N.; Khu, T.S. Modelling the combined effects of runoff reduction and increase in evapotranspiration for green roofs with a storage layer. Ecol. Eng. 2019, 127, 302-311. [CrossRef]

43. Shen, Q.R.; Li, T.; Cao, Y.; Pan, Y. Extensive green roof substrate composition based on sludge recycling. Environ. Sci. 2017, 38, 2953-2960.

44. Cascone, S.; Coma, J.; Gagliano, A.; Perez, G. The evapotranspiration process in green roofs: A review. Build. Environ. 2019, 147, 337-355. [CrossRef]

45. Li, J.S.; Yin, H.W.; Kong, F.H. Effects of a green roof on stormwater regulation and cost-benefit analysis. Environ. Sci. 2019, 40, 1803-1810.

46. Ebrahimian, A.; Wadzuk, B.; Traver, R. Evapotranspiration in green stormwater infrastructure systems. Sci. Total Environ. 2019, 688, 797-810. [CrossRef] [PubMed] 
47. Zhang, Z.; Szota, C.; Fletcher, D.T.; Willianms, S.G.N.; Farrell, C. Green roof storage capacity can be more important than evapotranspiration for retention performance. J. Environ. Manag. 2019, 232, 404-412. [CrossRef]

48. Li, X.Y.; Zhang, R.; Zhang, Z.S.; Yan, Q. Do climate simulations support the existence of East Asian monsoon climate in the Late Eocene? Palaeogeogr. Palaeoclimatol. Palaeoecol. 2018, 509, 47-57. [CrossRef]

49. Ge, Q.S.; Guo, X.F.; Zheng, J.Y.; Hao, Z.X. Meiyu in the middle and lower reaches of the Yangtze River since 1736. Chin. Sci. Bull. 2007, 52, 107-114. [CrossRef]

50. Lu, J.M.; Ju, J.H.; Tao, S.Y. Re-Discussion on East Asian Meiyu Rainy Season. Atmos. Ocean. Sci. Lett. 2013, 6, 279-283.

51. Zhou, H.G. Study on the mesoscale structure of the heavy rainfall on Meiyu front with dual-Doppler RADAR. Atmos. Res. 2009, 93, 335-357. [CrossRef]

52. Tao, S.Y.; Chen, L.X. A review of recent research on the East Asian summer monsoon in China. In Monsoon Meteorology; Chang, C.P., Krishnamurti, T.N., Eds.; Oxford University Press: Oxford, UK, 1987; pp. 60-92.

53. Tao, S.Y.; Zhu, W.M.; Zhao, W. Discussion on interannual variability of Meiyu. Chin. J. Atmos. Sci. 1998, 12, 13-21. (In Chinese)

54. Ding, Y.H. Summer monsoon rainfalls in China. J. Meteor. Soc. Jpn. 1992, 70, 373-396. [CrossRef]

55. Ding, Y.H. Seasonal march of the East Asian monsoon. In East Asian Monsoon; Chang, C.P., Ed.; World Scientific: Singapore, 2004; p. 564.

56. Wang, T.; Miao, J.P.; Sun, J.Q.; Fu, Y.-H. Intensified East Asian summer monsoon and associated precipitation mode shift under the 1.5 C global warming target. Adv. Clim. Chang. Res. 2018, 9, 102-111. [CrossRef]

57. Wang, B.; Lin, H. Rainy season of the Asian-Pacific summer monsoon. J. Clim. 2002, 15, 386-398. [CrossRef]

58. Ding, Y.H.; Chan, J.C.L. The East Asian summer monsoon: An overview, Meteorol. Atmos. Phys. 2005, 89, 117-142.

59. Ding, Y.H.; Ren, G.Y.; Zhao, Z.C.; Xu, Y.; Luo, Y.; Li, Q.; Zhang, J. Detection, causes and projection of climate change over China: An overview of recent progress. Adv. Atmos. Sci. 2007, 24, 954-971. [CrossRef]

60. Allen, G.R.; Pereira, S.L.; Raes, D.; Smith, M. Crop Evapotranspiration-Guidelines for Computing Crop Water Requirements; FAO Irrigation and drainage Paper No.56; Food and Agriculture Organization of the United Nations: Rome, Italy, 1998.

61. Weather in China. Available online: http://www.weather.com.cn/cityintro/101240101.shtml (accessed on 10 June 2017).

62. Liu, X.Y.; Ma, Z.X.; Yang, Y.G.; Wang, D.Y. The groundwater characteristics and its emergency water source in Nanchang. Resour. Surv. Environ. 2006, 27, 33-38. (In Chinese)

63. Lan, Y.Y.; Chen, J.M.; Wang, J.X. Analysis of dynamic characteristics and influencing factors of groundwater in Nanchang city. J. Nanchang Inst. Technol. 2017, 7, 36. (In Chinese)

64. Gregoire, B.G.; Clausen, J.C. Effect of a modular extensive green roof on stormwater runoff and water quality. Ecol. Eng. 2011, 37, 963-969. [CrossRef]

65. Getter, K.L.; Rowe, D.B. The role of extensive green roofs in sustainable development. HortScience 2006, 41, 1276-1285. [CrossRef]

66. Hui, S.C.M. Benefits and Potential Applications of Green Roof Systems in Hong Kong. In Proceedings of the 2nd Megacities International Conference, Guangzhou, China, 1-2 December 2006.

67. Burszta-Adamiak, E.; Mrowiec, M. Modelling of green roofs' hydrologic performance using EPA's SWMM. Water Sci. Technol. 2013, 68, 36-42. [CrossRef] [PubMed]

68. Versini, P.A.; Ramier, D.; Berthier, E.; De Gouvello, B. Assessment of the hydrological impacts of green roof: From building scale to basin scale. J. Hydrol. 2015, 524, 562-575. [CrossRef]

69. Li, J.F.; Zhang, Q.; Chen, Y.D.; Singh, P.V. Future joint probability behaviors of precipitation extremes across China: Spatiotemporal patterns and implications for flood and drought hazards. Glob. Planet. Chang. 2015, 124, 107-122. [CrossRef]

70. Li, W.; Zhai, P.M.; Cai, J.H. Research on the Relationship of ENSO and the Frequency of Extreme Precipitation Events in China. Adv. Clim. Chang. Res. 2011, 2, 101-107. [CrossRef]

71. Huang, S.Z.; Huang, Q.; Chang, J.X.; Leng, G.; Chen, Y. Variations in precipitation and runoff from a multivariate perspective in the Wei River Basin, China. Quat. Int. 2017, 440, 30-39. [CrossRef] 
72. Huo, Z.Y.; Ruan, Z.; Wei, M.; Ge, R.; Li, F.; Ruan, Y. Statistical characteristics of raindrop size distribution in south China summer based on the vertical structure derived from VPR-CFMCW. Atmos. Res. 2019, 222, 47-61. [CrossRef]

73. Zhong, R.; Chen, X.H.; Lai, C.G.; Wang, Z.; Lian, Y.; Yu, H.; Wu, X. Drought monitoring utility of satellite-based precipitation products across mainland China. J. Hydrol. 2019, 568, 343-359. [CrossRef]

74. USEPA. Storm Water Management Model Application Manual; USEPA: Washington, DC, USA, 2009.

75. Cheng, D.; Chen, Z.H.; Fang, Y. The analysis of the designed storm pattern over Yichang. Torrential Rain Disasters 2015, 34, 249-253. (In Chinese)

76. Dai, Y.X.; Wang, Z.H.; Dai, L.D.; Cao, Q.; Wang, T. Application of Chicago Hyetograph Method in Design of Short Duration Rainstorm Pattern. Arid Meteorol. 2017, 35, 1061-1069. (In Chinese)

77. Ni, Z.N.; Li, Q.F.; Du, F.R.; Jiang, H.T. Study on design of rainstorm pattern based on short duration in Nanjing City. J. Water Resour. Water Eng. 2019, 30, 57-62. (In Chinese)

78. Sun, W.; Shen, J.; Jiang, X.X.; Gu, M.; Wang, W.J.; Xu, X. Research and analysis of storm pattern over Suzhou City. The Formation Mechanisms, Prediction, Early Warning and Risk Assessment of Hydro-meteorological Disasters. In Proceedings of the 35th Annual Meeting of China Meteorological Society, Hefei, China, 24-26 October 2018; Volume 28, pp. 443-448. (In Chinese).

79. Zhu, Y.N. Selection of Design Rainfall Pattern: Case of Hangzhou. China Water Wastewater 2016, 32, 94-96. (In Chinese)

80. USEPA. Storm Water Management Model User's Manual; USEPA: Washington, DC, USA, 2015.

81. Lee, J.Y.; Lee, M.J.; Han, M. A pilot study to evaluate runoff quantity from green roofs. J. Environ. Manag. 2015, 152, 171-176. [CrossRef] [PubMed]

82. Hargreaves, H.G.; Merkley, P.G. Irrigation Fundamentals; Water Resources Publication: Littleton, CO, USA, 1998.

83. Brutsaert, W.; Stricker, H. An advection-aridity approach to estimate actual regional evapotranspiration. Water Resour. Res. 1979, 15, 443-450. [CrossRef]

84. Granger, R.J.; Gray, D.M. Evaporation from natural nonsaturated surface. J. Hydrol. 1989, 111, $21-29$. [CrossRef]

85. Ugwu, A.I.; Ugwuanyi, J.U. Performance assessment of Hargreaves model in estimating solar radiation in Abuja using minimum climatological data. Int. J. Phys. Sci. 2011, 6, 7285-7290.

86. Hargreaves, G.H.; Samani, Z.A. Reference crop evapotranspiration from ambient air temperature. Appl. Eng. Agric. 1985, 1, 96-99. [CrossRef]

87. Jensen, M.E.; Burman, R.D.; Allen, R.G. Evapotranspiration and irrigation water requirements. In ASCE Manual and Report on Engineering Practice No. 70; ASCE: New York NY, USA, 1990.

88. Marasco, D.E.; Culligan, P.J.; McGillis, W.R. Evaluation of common evapotranspiration models based on measurements from two extensive green roofs in New York City. Ecol. Eng. 2015, 84, 451-462. [CrossRef]

89. Xu, C.Y.; Chen, D. Comparison of seven models for estimation of evapotranspiration and groundwater recharge using lysimeter measurement data in Germany. Hydrol. Process. 2005, 19, 3717-3734. [CrossRef]

90. Kim, H.; Kaluarachchi, J.J. Complementary relationship for estimating evapotranspiration using the Granger-Gray model: Improvements and comparison with a remote sensing method. Hydrol. Earth Syst. Sci. 2017, 1-28. [CrossRef]

91. Carmen, B.N.; Hunt, F.W.; Anderson, A.R. Volume Reduction Provided by Eight Residential Disconnected Downspouts in Durham, North Carolina. J. Environ. Eng. 2016, 142, 05016002. [CrossRef]

92. Carpenter, D.D.; Kaluvakolanu, P. Effect of roof surface type on storm-water runoff from full-scale roofs in a temperate climate. J. Irrig. Drain. Eng. 2011, 137, 161-169. [CrossRef]

93. Carter, T.L.; Rasmussen, T.C. Hydrologic behavior of vegetated roofs. J. Am. Water Resour. Assoc. 2006, 42, 1261-1274. [CrossRef]

94. Getter, K.L.; Rowe, D.B.; Andresen, J.A. Quantifying the effect of slope on extensive green roof stormwater retention. Ecol. Eng. 2007, 31, 225-231. [CrossRef]

95. Tabares-Velasco, P.C.; Zhao, M.; Peterson, N.; Srebric, J.; Berghage, R. Validation of predictive heat and mass transfer green roof model with extensive green roof field data. Ecol. Eng. 2012, 47, 165-173. [CrossRef] 
96. Kwok, J.; Wong, W.; Lau, L.S. From the 'urban heat island' to the 'green island'? A preliminary investigation into the potential of retrofitting green roofs in Mongkok district of Hong Kong. Habitat Int. 2013, 39, 25-35.

97. Coutts, A.M.; Daly, E.; Beringer, J.; Tapper, N.J. Assessing practical measures to reduce urban heat: Green and cool roofs. Build. Environ. 2013, 70, 266-276. [CrossRef]

(C) 2020 by the authors. Licensee MDPI, Basel, Switzerland. This article is an open access article distributed under the terms and conditions of the Creative Commons Attribution (CC BY) license (http://creativecommons.org/licenses/by/4.0/). 